E. B. Gareth Jones*, Bandarupalli Devadatha, Mohamed A. Abdel-Wahab, Monika C. Dayarathne, Sheng-Nan Zhang, Kevin D. Hyde, Jian-Kui (Jack) Liu, Ali H. Bahkali, Vemuri V. Sarma, Sanja Tibell, Leif Tibell, Meng-Meng Wang, Fang Liu and Lei Cai

\title{
Phylogeny of new marine Dothideomycetes and Sordariomycetes from mangroves and deep-sea sediments
}

https://doi.org/10.1515/bot-2019-0014

Received 5 March, 2019; accepted 16 July, 2019; online first 14 August, 2019

\begin{abstract}
This paper documents six new saprobic marine fungi and one new genus based on morphology and multi-gene phylogenies. Three Dothideomycetes, and members of the Pleosporales, are introduced: Pseudomassariosphaeria triseptata sp. nov. was recognized as a mangrove species in Amniculicolaceae, and Salsuginea phoenicis sp. nov. was discovered as a second member of Salsugineaceae. A new genus Raghukumaria with Raghukumaria keshaphalae sp. nov., recovered from mangroves, is phylogenetically sister to Halomassarina and nests in the Trematosphaeriaceae. Three new species are referred to the Sordariomycetes: Coniochaeta marina (Coniochaetales, Coniochaetaceae) on driftwood; Fusicolla bharatavarshae (Hypocreales, Nectriaceae) is introduced with asexual and sexual morphs, on decayed
\end{abstract}

*Corresponding author: E. B. Gareth Jones, Department of Botany and Microbiology, College of Science, King Saud University, P.O. Box 2455, Riyadh 11451, Kingdom of Saudi Arabia, e-mail: torperadgj@gmail.com Bandarupalli Devadatha and Vemuri V. Sarma: Fungal Biotechnology Lab, Department of Biotechnology, School of Life Sciences, Pondicherry University, Kalapet, Pondicherry 605014, India. https://orcid.org/0000-0001-6400-5407 (B. Devadatha) Mohamed A. Abdel-Wahab: Department of Botany and Microbiology, College of Science, King Saud University, P.O Box 2455, Riyadh 11451, Kingdom of Saudi Arabia; and Department of Botany and Microbiology, Faculty of Science, Sohag University, Sohag 82524, Egypt

Monika C. Dayarathne: Center of Excellence in Fungal Research, Mae Fah Luang University, Chiang Rai 57100, Thailand; School of Science, Mae Fah Luang University, Chiang Rai 57100, Thailand; World Agro Forestry Centre East and Central Asia Office, 132 Lanhei Road, Kunming 650201, P.R. China; and Key Laboratory for Plant Biodiversity and Biogeography of East Asia (KLPB), Kunming Institute of Botany, Chinese Academy of Science, Kunming 650201, Yunnan, P.R. China mangrove wood of Avicennia marina; and Fusarium sedimenticola (Hypocreales, Nectriaceae) is new to the Fusarium solani species complex (FSSC) from deep-sea sediment.

Keywords: Coniochaetales; deep sea; estuarine palm; Hypocreales; Pleosporales.

\section{Introduction}

Aquatic marine fungi are a diverse taxonomic group, occurring worldwide and on a range of substrates (Hyde and Jones 1988, Jones and Pang 2012, 2017). Since the last special issue on marine mycology in Botanica Marina there have been great strides in our understanding of marine fungi (Xu et al. 2016, 2017, 2018, Raghukumar 2017, Amend et al. 2019, Gladfelter et al. 2019, Jones et al. 2019). Many marine fungi have been introduced,

Sheng-Nan Zhang: Department of Entomology and Plant Pathology, Faculty of Agriculture, Chiang Mai University, Chiang Mai 50200, Thailand; and Centre of Excellence in Fungal Research, Institute of Excellence in Fungal Research and School of Science, Mae Fah Luang University, Chiang Rai, 57100, Thailand

Kevin D. Hyde: Centre of Excellence in Fungal Research, Institute of Excellence in Fungal Research and School of Science, Mae Fah Luang University, Chiang Rai, 57100, Thailand; and Emeritus Professor in Kunming Institute of Botany, Chinese Academy of Sciences, Yunnan, P.R. China

Jian-Kui (Jack) Liu: School of Life Science and Technology, University of Electronic Science and Technology of China, Chengdu 611731, P.R. China

Ali H. Bahkali: Department of Botany and Microbiology, College of Science, King Saud University, P.O Box 2455, Riyadh 11451, Kingdom of Saudi Arabia

Sanja Tibell and Leif Tibell: Systematic Biology, Department of Organismal Biology, Evolutionary Biology Centre, Uppsala University, Norbyvägen 18D, 75236 Uppsala, Sweden

Meng-Meng Wang, Fang Liu and Lei Cai: State Key Laboratory of Mycology, Institute of Microbiology, Chinese Academy of Sciences, Beijing 100101, P.R. China 
others transferred to other taxa as the result of a wider use of sequencing data (see www.marinefungi.org). The 15th International Marine and Freshwater Symposium (IMFMS) held in Xiamen China provided greater input to the understanding of deep-sea marine fungi with a number of keynote lectures (see elsewhere in this volume). Currently the number of accepted marine fungi stands at 1257 species in 538 genera, 168 families, and 74 orders (Jones et al. 2019). As different habitats and substrates are examined for marine fungi, so this number can be expected to increase (Hyde et al. 2017, 2018). Marine fungi are also being recollected and sequenced to provide molecular data to resolve their taxonomic placements (Hyde et al. 2017). Studies of fungi isolated from marine algae and from deep-sea water will surely continue to expand our knowledge of marine fungi as shown by Garzoli et al. (2018) for seaweeds and Xu et al. (2016, 2018) for deep water habitats. Recent taxonomic studies on marine fungi recovered many new taxa worldwide, and six are documented in this issue.

\section{Materials and methods}

Collection details for the new marine fungi are outlined in the descriptions with cultures and dried specimens deposited in the following collections and herbaria: for Raghukumaria keshaphalae E.B.G. Jones et Abdel-Wahab, sp. nov. and Fusicolla bharatavarshae Devadatha, V.V Sarma et E.B.G Jones, sp. nov, herbarium specimens and living cultures were deposited at Ajrekar Mycological Herbarium (AMH), Agharkar Research Institute (ARI) (http://aripune.org/ajrekar-mycological-herbarium) and National Fungal Culture Collection of India (NFCCI), Pune, India (http://nfcci.aripune.org/20); the type specimen of Fusarium sedimenticola M.M. Wang, F. Liu et L. Cai, sp. nov. was deposited in the Mycological Herbarium of Institute of Microbiology, Chinese Academy of Sciences, Beijing, China (HAMS, http://www.cvh.ac.cn/her/hmas), with ex-type living culture deposited in China General Microbiological Culture Collection Centre (CGMCC, http:// www.cgmcc.net/), Beijing, China (www.cgmcc.net); the type specimen of Pseudomassariosphaeria triseptata E.B.G. Jones et Abdel-Wahab, sp. nov. was deposited in Centraalbureau voor Schimmelcultures (CBS), Westerdijk Fungal Biodiversity Institute, Utrecht, The Netherlands (http://www.westerdijkinstitute.nl); the type material of Salsuginea phoenicis S.N. Zhang, E.B.G. Jones, K.D. Hyde et J.K. Liu, sp. nov. was deposited in Mae Fah Luang University (MFLU), Chiang Rai, Thailand (mfumycology. herbarium@gmail.com); the type specimen of Coniochaeta marina Dayarathne, S. Tibell, Tibell, et K.D. Hyde, sp. nov. was deposited in MFLU and the ex-type living culture deposited in Mae Fah Luang University Culture Collection (MFLUCC), Chiang Rai, Thailand.

Material examination and laboratory procedures followed those outlined in Jones and Hyde (1988). Morphological characters were observed and photographed by using stereo microscopes and compound microscopes fitted with a digital camera. Fungal genomic DNA was extracted from fresh mycelia or fruiting bodies by using commercial Fungi Genomic DNA Purification Kits (MOBIO; Mo Bio Laboratories, Carlsbad, CA, USA; Ezup Column Fungi Genomic DNA Purification Kit, Sangon Biotech Co., Ltd, Shanghai, China; Thermo Scientific Gene JET Plant Genomic DNA Purification kit, Waltham, MA, USA). Polymerase chain reactions (PCR) were performed for the large subunits of the nuclear ribosomal RNA gene (LSU), the small subunits of the nuclear ribosomal RNA gene (SSU), the internal transcribed spacers of the ribosomal RNA gene including the 5.8S (ITS), the translation elongation factor-1 alpha (TEF1 $\alpha$ ), the second largest subunit of RNA polymerase II (RPB2), and the partial beta-tubulin gene (TUB2). The primers used in PCR were: LROR/LR5 and LR7 for LSU (Vilgalys and Hester 1990), NS1/NS4 for SSU (White et al. 1990), ITS4/ITS5 for ITS (White et al. 1990), EF1-983F/EF1-2218R for TEF1 $\alpha$ (Rehner and Buckley 2005), and fRPB2-5F/fRPB2-7cR for RPB2 (Liu et al. 1999) and Bt2a/Bt2b for TUB2 (Trouillas et al. 2011). Purification and sequencing of PCR products were carried out with the primers mentioned above. Phylogenetic analyses used for the different species are detailed in the individual species notes.

\section{Results: taxonomy}

Dothideomycetes O.E. Erikss. et Winka, Myconet 1: 5 (1997).

The class Dothideomycetes comprises 33 orders and 175 families with a huge diversity on various hosts, and in different ecosystems including many marine taxa, especially from mangroves (Suetrong et al. 2009, Pang et al. 2011, Hyde et al. 2013). Three new taxa are introduced in this article.

Pleosporales Luttr. ex M.E. Barr, Prodromus to class Loculoascomycetes: 67 (1987) (Pleosporomycetidae). Pleosporales is the largest order in Dothideomycetes, comprising 75 families and 52 genera in Pleosporales incertae 
sedis (Zhang et al. 2012, Liu et al. 2017, Wijayawardene et al. 2017, 2018).

Amniculicolaceae Y. Zhang, C.L. Schoch, J. Fourn., Crous et K.D. Hyde, Studies in Mycology 64: 95 (2009).

The family Amniculicolaceae was introduced to accommodate the genera Amniculicola Y. Zhang et K.D. Hyde, Murispora Y. Zhang, J. Fourn. et K.D. Hyde, and Neomassariosphaeria Y. Zhang, J. Fourn. et K.D. Hyde (Zhang et al. 2009), and subsequently the genus Pseudomassariosphaeria Phukhams., Ariyaw., Camporesi et K.D. Hyde (Ariyawansa et al. 2015).

Pseudomassariosphaeria Phukhams., Ariyaw., Camporesi et K.D. Hyde, Fungal Diversity 75: 35 (2015).

The genus was introduced to accommodate the type species Pseudomassariosphaeria bromicola Phukhams., Ariyaw., Camporesi et K.D. Hyde. Subsequently, Ariyawansa et al. (2015) transferred Neomassariosphaeria to Lindgomycetaceae, and introduced the genus Pseudomassariosphaeria, with a new combination Pseudomassariosphaeria grandispora (Sacc.) Phukhams., Ariyaw. et K.D. Hyde (三Leptosphaeria grandispora Sacc.) (Ariyawansa et al. 2015).

\section{Pseudomassariosphaeria triseptata E.B.G. Jones et Abdel-Wahab, sp. nov. (Figures 1A-E and 2)}

(MycoBank MB829625) Saprobic on decaying driftwood. Sexual morph: Ascomata 230-380 $\mu \mathrm{m}$ diam., immersed to erumpent, subglobose to flask-shaped with flattened base, single or aggregated and confluent in groups of 2-5 ascomata, papillate, ostiolate, periphysate (Figure 1A). Papillae $70-100 \mu \mathrm{m}$ long, 90-115 $\mu \mathrm{m}$ wide, periphysate 1.5-2 $\mu \mathrm{m}$ thick. Peridium $26-50 \mu \mathrm{m}$ thick, thicker and darker in the upper part than the lower part, two-layered, forming textura angularis; outer layer 12-25 $\mu \mathrm{m}$ thick consisting of polygonal melanized cells, reddish-brown to dark-brown, inner layer $14-22 \mu \mathrm{m}$ thick, of hyaline to light-brown polygonal cells. Pseudoparaphyses $1.5-2.5 \mu \mathrm{m}$ wide, numerous, embedded in a gelatinous matrix, branched, septate, anastomosing above the asci (Figure 1B). Asci $87-176 \times 19-33 \mu \mathrm{m}(\overline{\mathrm{x}}=121.5 \times 24.5 \mu \mathrm{m}$, $\mathrm{n}=30$ ), 4 or 8 -spored, fissitunicate, clavate, ellipsoidal, with ocular chamber and faint ring, pedunculate (Figure 1B, C). Ascospores 35-50 ×10-13 $\mu \mathrm{m}(\overline{\mathrm{x}}=43.5 \times 11.0$ $\mu \mathrm{m}, \mathrm{n}=50$ ), hyaline, 1-3-septate, deeply constricted in the median septum, surrounded by gelatinous sheath 2-6 $\mu \mathrm{m}$ wide, overlapping multiseriate (Figure 1D-E), senescent ascospores light-brown to brown in color with smooth or roughened surface. Asexual morph: Unknown.

Etymology In reference to the 3-septate ascospores.

\section{Known geographical distribution UK (England).}

Material examined UK, England, Southsea, decaying driftwood, 18th January 2013, E.B.G. Jones, CBS H-23852 (holotype).

Habitat Saprobic on decaying driftwood, Southsea, Hampshire, England.

Notes: The genus Pseudomassariosphaeria (DNA extracted directly from fruit body) was established to accommodate Pseudomassariosphaeria bromicola that was described from a dead terrestrial stem of Bromus sterilis L. (Ariyawansa et al. 2015). Pseudomassariosphaeria triseptata formed a monophyletic clade with Murispora and Pseudomassariosphaeria but with low statistical support. Murispora and Pseudomassariosphaeria species share common characteristics that include dark-brown to black ascomata that are erumpent to superficial with periphysate ostiole, two-layered peridium, numerous pseudoparaphyses in gel, fissitunicate asci with ocular chambers and ascospores with wide gelatinous sheath. The two genera differ in the morphology of the ascospores; Murispora species has muriform ascospores that are hyaline to brown, while Pseudomassariosphaeria species have hyaline phragmospores. Pseudomassariosphaeria triseptata differs from the other two Pseudomassariosphaeria species by possessing larger, 3-septate ascospores that are ellipsoidal (Table 1). Ascospores in P. bromicola and Pseudomassariosphaeria grandispora are fusoid with narrow tapering ends and 8-10-septate (Saccardo 1878, Zhang et al. 2009, Ariyawansa et al. 2015).

Salsugineaceae K.D. Hyde et Tibpromma, in Hyde et al., Fungal Diversity 63: 227 (2013).

Salsugineaceae was introduced to accommodate Salsuginea K.D. Hyde and Acrocordiopsis Alias et E.B.G. Jones, but the position of the latter in the family is not well-supported (Ariyawansa et al. 2015, Zhang et al. 2019).

Salsuginea K.D. Hyde, Botanica Marina 34 (4): 315 (1991). Salsuginea was introduced with Salsuginea ramicola K.D. Hyde as the type species on mangrove wood of intertidal Aegiceras sp. collected in Thailand (Hyde 1991). In this article we introduce a second species Salsuginea phoenicis. 

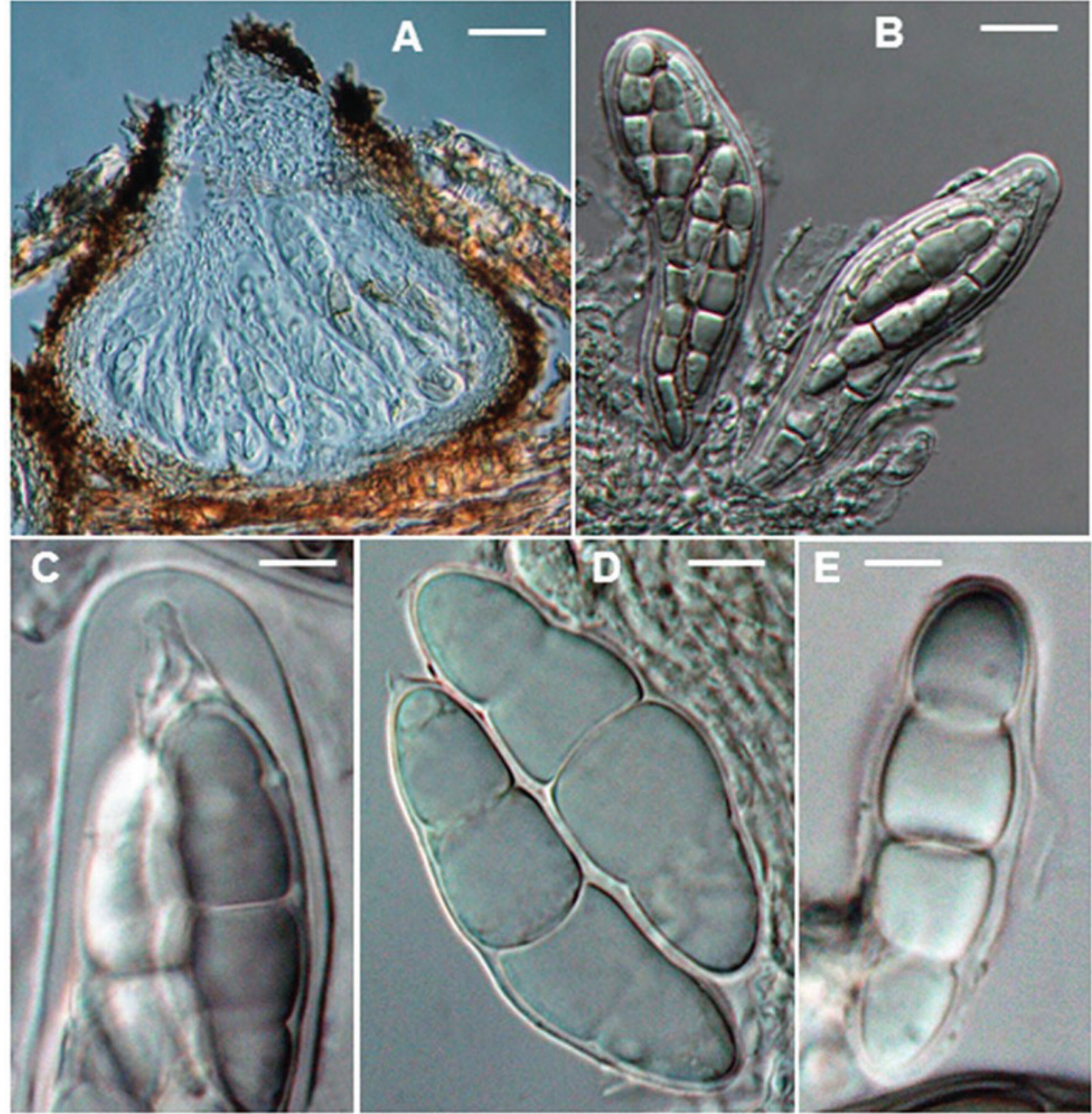

Figure 1: Pseudomassariosphaeria triseptata (CBS H-23852, holotype).

(A) Vertical section through ascoma. (B) Mature asci and pseudoparaphyses. (C) Apical part of an ascus showing ocular chamber and faint ring. (D-E) Variously shaped ascospores surrounded by gelatinous sheath. Scale bars: $A=40 \mu \mathrm{m} ; B=20 \mu \mathrm{m} ; C-E=6 \mu \mathrm{m}$.

Salsuginea phoenicis S.N. Zhang, E.B.G. Jones, K.D. Hyde et J.K. Liu, sp. nov. (Figures $3 A-Q$ and 4)

(MycoBank MB829547) Sexual morph: Ascomata on host surface $280-500 \mu \mathrm{m}$ in diam., in vertical section 410-480 $\mu \mathrm{m}$ high, 680-980 $\mu \mathrm{m}$ in diam., solitary, immersed to erumpent, black, carbonaceous, conical or subglobose, with a central ostiole or papilla, clypeate. Peridium thick, up to $55 \mu \mathrm{m}$ wide, composed of brown cells of textura epidermoidea and inner layers with cells of textura angularis. Clypeus composed of host cells interspersed with darkened fungal tissue. Hamathecium comprising 1-1.5 $\mu \mathrm{m}$ wide, numerous, anastomosing, branched, septate trabeculate pseudoparaphyses, embedded in a gelatinous matrix. Asci $140-275 \times 23-30 \mu \mathrm{m}, 8$-spored, bitunicate, fissitunicate, cylindric-clavate, pedicellate, with an apical apparatus consisting of a large distinctive ocular 


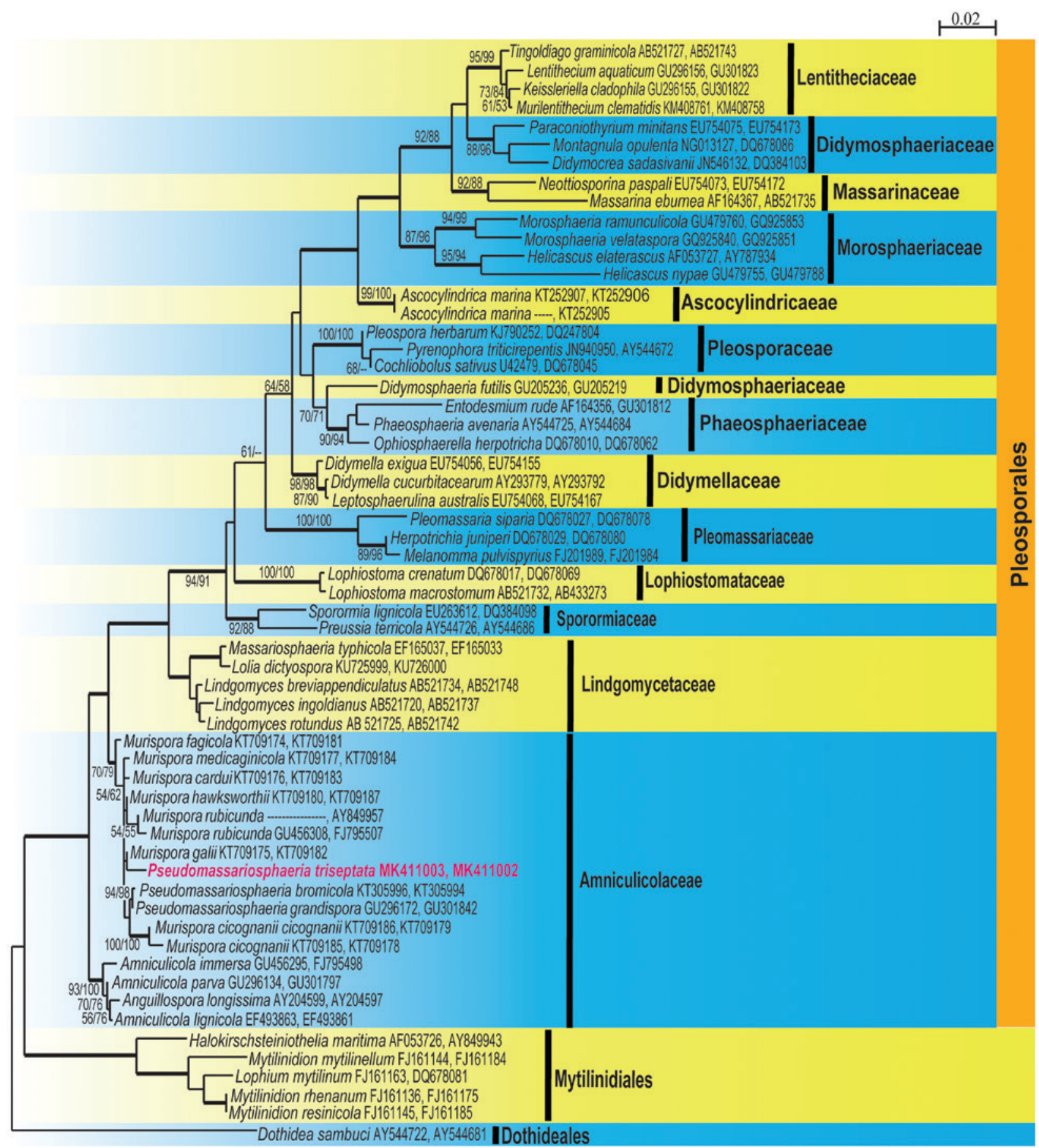

Figure 2: Phylogenetic relationship of Pseudomassariosphaeria triseptata with related taxa in Pleosporales based on the nucleotide sequences of the combined SSU and LSU rDNA.

The maximum likelihood (ML) tree (-In likelihood =12,436.25) was constructed in PAUP* v.4.0b10 (Swofford 2002).

The maximum parsimonious data set of the combined genes consisted of 58 in-group taxa and 1 out-group taxon with 1006 total characters, of which 675 were constant, 109 parsimony-uninformative and 222 parsimony-informative. The parsimony analyses of the data matrix yielded 64 equally most parsimonious trees with a tree length of 951 steps (consistency index $[\mathrm{Cl}]=0.4669$, homoplasy index $[\mathrm{HI}]=0.5331$, retention index $[\mathrm{RI}]=0.7733$, rescaled consistency index $[R C]=0.361$ ). Phylogenetic trees obtained from ML, maximum parsimony (MP) and Bayesian inference posterior probabilities (BIPP) were similar in topology. Bootstrap support on the nodes represents $M L$ and $M P \geq 50 \%$. Branches with a BIPP of $100 \%$ are in bold. The tree is rooted to Dothidea sambuci (Pers.) Fr. The new fungus is in red font, and the sequences were submitted to GenBank with accession numbers LSU = MK411002, $\mathrm{SSU}=$ MK411003. 


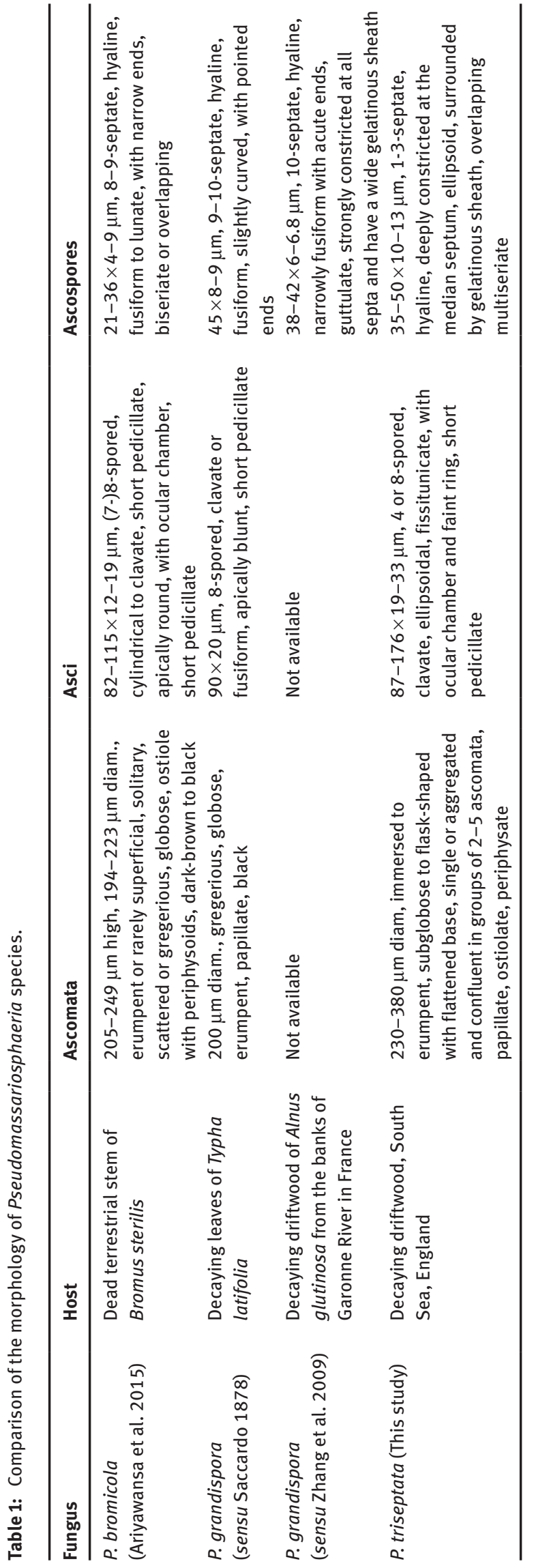

chamber and prominent ring. Ascospores 46-62 $\times 16-24$ $\mu \mathrm{m}(\overline{\mathrm{x}}=52.00 \times 18.00 \mu \mathrm{m}, \mathrm{n}=20)$, uniseriate or biseriate, hyaline to brown, broad fusiform or ellipsoidal, 2-celled and almost equally, strongly constricted at the central septum, with hyaline apical germ pores, smoothwalled, lacking a mucilaginous sheath. Asexual morph: Undetermined.

Culture characteristics: Colonies growing well on potato dextrose agar (PDA) and malt extract agar (MEA), and attaining $13 \mathrm{~mm}$ diam. on PDA within 21 days at $25^{\circ} \mathrm{C}$ under natural light, velvety, circular, milky white and central darker or pale brown, reverse brown, with a margin of translucent, milky white to hyaline mycelia.

Etymology In reference to the host mangrove palm Phoenix paludosa Roxb.

Known geographical distribution The Gulf of Thailand, Thailand.

Material examined Thailand, Tambon Wan Yao, Amphoe Khlung, Chanthaburi, $12^{\circ} 26^{\prime} 43^{\prime \prime} \mathrm{N}, 102^{\circ} 15^{\prime} 47^{\prime \prime}$ E, sea level on decaying petiole of Phoenix paludosa from intertidal zone, 25 April 2017, S.N. Zhang, SNT132, MFLU 19-0015 (holotype); same collection details HKAS 102605, isotype.

Habitat Saprobic on decaying wood and palms submerged in brackish waters in mangroves.

Notes: The genus Salsuginea was established to accommodate a mangrove species Salsuginea ramicola and originally thought to be similar to Helicascus Kohlm., but differs from the latter by its textura porrecta structure of the peridium and ascospores with apical germ pores (Hyde 1991, Hyde et al. 2013). In this study, we introduce a second Salsuginea species Salsuginea phoenicis, which was associated with the palm Phoenix paludosa in a Thai mangrove. Salsuginea phoenicis has typical characters of the genus, such as large ascomata with a pseudoclypeus, thick peridium, a ring surrounding the ocular chamber in the ascus and ascospores with hyaline apical germ pores. Salsuginea phoenicis however differs from S. ramicola (marinefungi.org) in its relatively smaller ascomata, asci, ascospores and thicker peridium. The uniseriate or biseriate ascospores with two almost equally sized cells in $S$. phoenicis are also different from the obviously unequal cells in S. ramicola.

The multi-gene dataset comprised 37 taxa and 3955 characters. Randomized axelerated maximum likelihood (RAxML), maximum parsimony (MP) and Bayesian analyses were conducted and resulted in generally congruent topologies, and RAxML analysis based on 

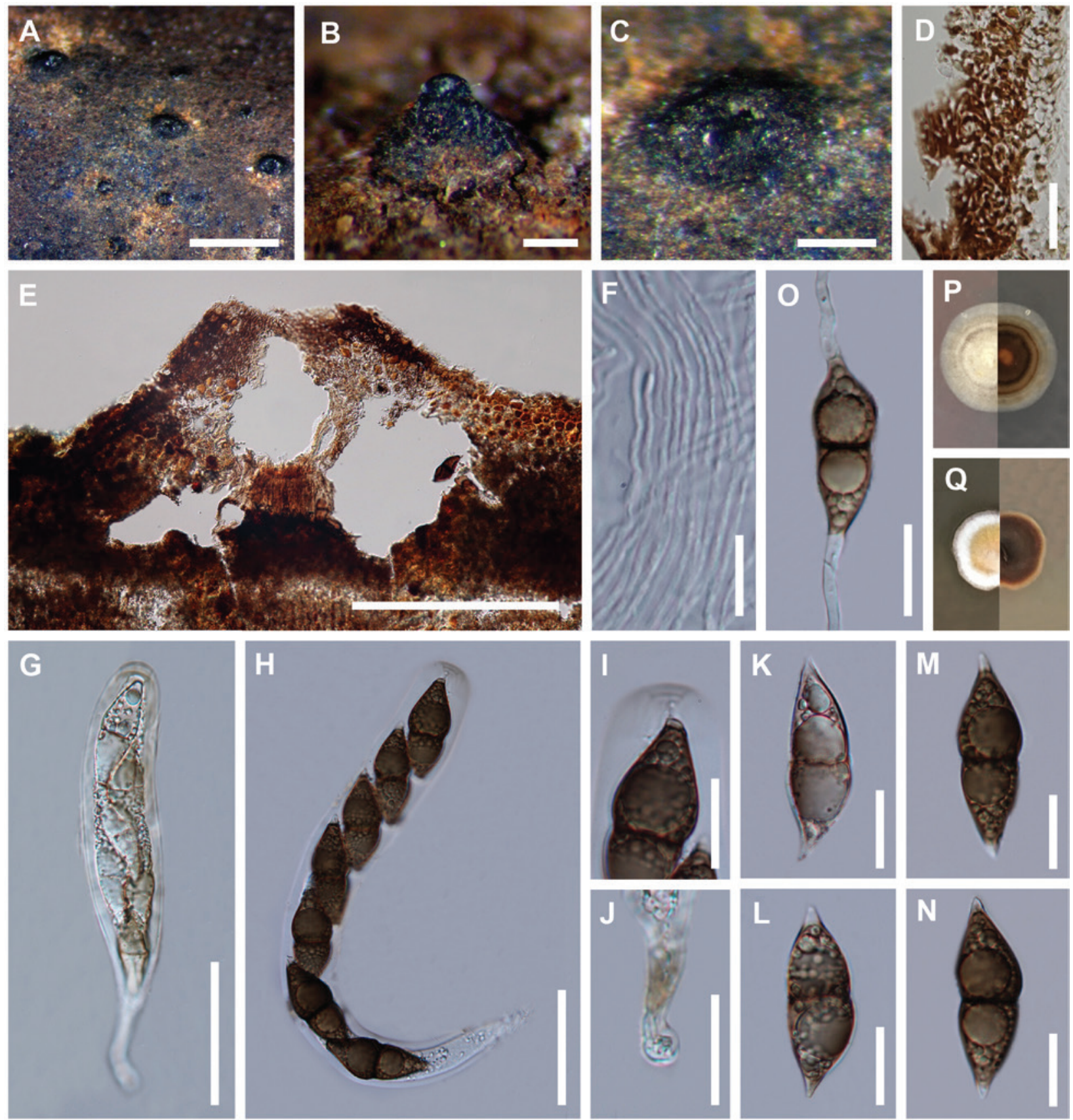

Figure 3: Salsuginea phoenicis (MFLU 19-0015, holotype).

(A-C) Ascomata on substrate surface. (D) Peridium. (E) Vertical section of ascoma. (F) Pseudoparaphyses. (G-H) Ascus. (I) Apical structure of ascus. (J) Pedicellate base of ascus. (K-N) Ascospores. (0) Germinating ascospore. (P) Colony on potato dextrose agar (left: top view, right: bottom view). (Q) Colony on malt extract agar (left: top view, right: bottom view). Scale bars: $A=1000 \mu \mathrm{m} ; \mathrm{B}-\mathrm{C}, \mathrm{E}=200 \mu \mathrm{m} ; \mathrm{G}-\mathrm{H}=50 \mu \mathrm{m} ; \mathrm{D}$, $\mathrm{I}-\mathrm{O}=20 \mu \mathrm{m} ; \mathrm{F}=10 \mu \mathrm{m}$.

LSU, SSU rDNA, TEF1 $\alpha$ and RPB2 yielded the best sorting tree (Figure 4) with a final optimization likelihood value of $-19,916.355634$. Maximum parsimony analyses indicated that 2775 characters were constant, 243 parsimony uninformative variable characters and
937 parsimony-informative characters. A heuristic search yielded four equally most parsimonious trees (tree length $=3217$ steps, consistency index $(\mathrm{CI})=0.534$, retention index $(\mathrm{RI})=0.637$, rescaled consistency index $(\mathrm{RC})=0.340$, homoplasy index $(\mathrm{HI})=0.466)$. The new 


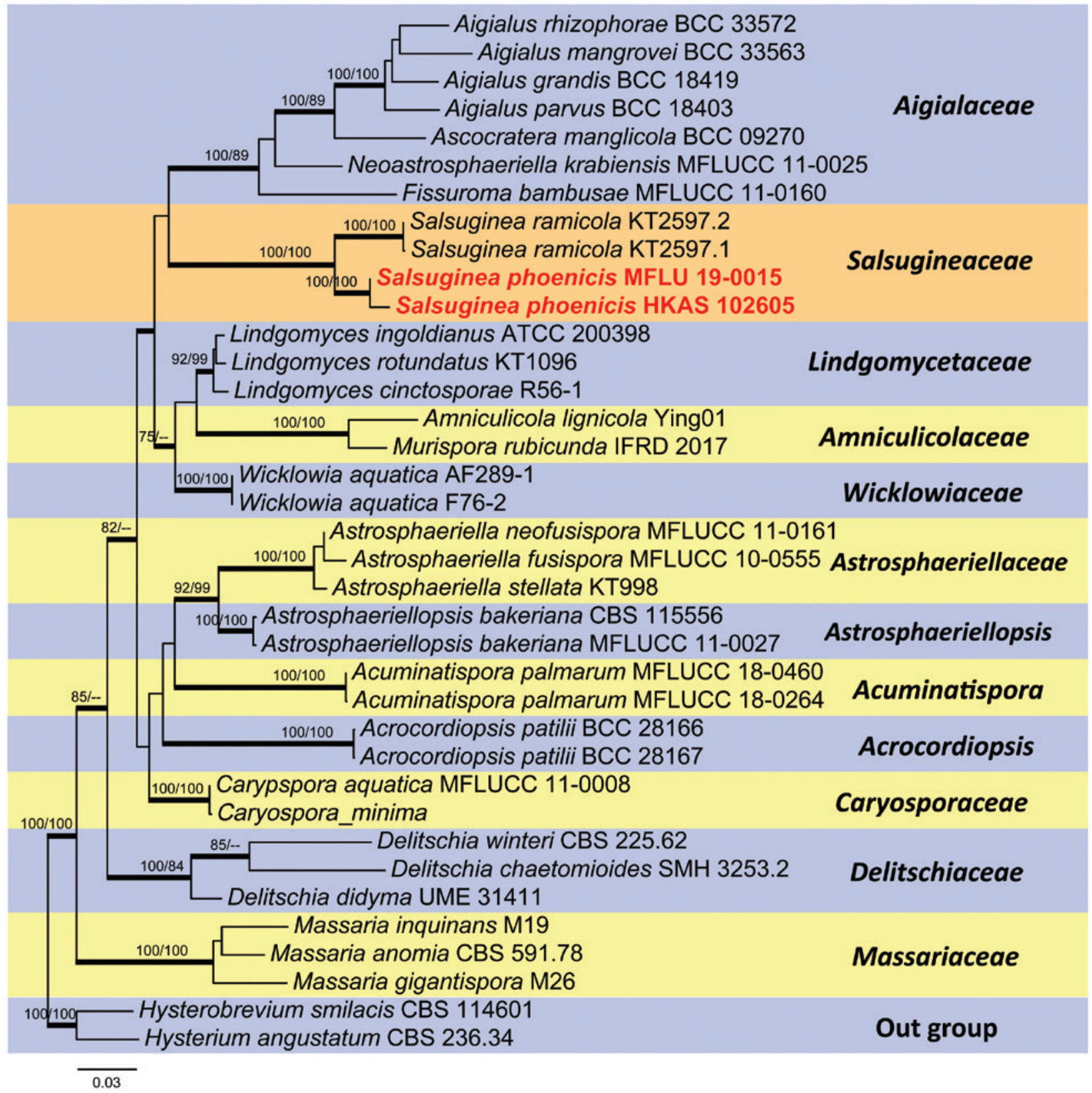

Figure 4: Randomized axelerated maximum likelihood (RAxML) phylogram of Salsugineaceae and selected families in Pleosporales based on combined LSU, SSU rDNA, TEF1 $\alpha$ and RPB2 sequenced data.

Bootstrap values for maximum likelihood (ML) and maximum parsimony (MP) equal to or greater than $75 \%$ are placed above the branches and indicated as ML/MP. Branches with Bayesian posterior probabilities (PP) from Markov chain Monte Carlo (MCMC) analysis equal or greater than 0.95 are in bold. The new isolates are indicated in bold red type.

isolates of Salsuginea phoenicis SNT132a and SNT132b used in this study were submitted to GenBank, and the accession numbers are SNT132a (LSU $=$ MK405280, TEF1 $\alpha=$ MK404650), SNT132b (LSU = MK405281).

The phylogenetic tree showed that the new isolates of Salsuginea phoenicis clustered with Salsuginea ramicola and are highly supported in Salsugineaceae
(Hyde et al. 2013). However, the phylogenetic positions of Salsugineaceae and its related genus Acrocordiopsis (Suetrong et al. 2009, Hyde et al. 2013) were not stable in our analyses, because of insufficient taxon sampling. Further collections of relevant taxa and new sequence data are still required for resolving their taxonomic positions. 
Trematosphaeriaceae K.D. Hyde, Y. Zhang ter, Suetrong et E.B.G. Jones, Cryptogamie Mycology 32 (4): 347 (2011). Trematosphaeriaceae was introduced by Suetrong et al. (2011) to accommodate the genera Falciformispora K.D. Hyde, Halomassarina Suetrong, Sakay., E.B.G. Jones et C.L. Schoch and Trematosphaeria Fuckel. The main distinguishing characters of the family are medium-sized rounded ascomata with a papillate ostiole, a relatively wide, coriaceous peridium, cellular pseudoparaphyses and cylindroclavate asci. In this article we introduce a fourth genus Raghukumaria Devadatha, V.V Sarma et E.B.G Jones, based on morphological and molecular characteristics.

\section{Raghukumaria Devadatha, V.V Sarma et E.B.G Jones, gen. nov.}

(MycoBank MB 829062) Saprobic on decayed mangrove wood. Sexual morph: Ascomata globose to oval, gregarious, immersed, erumpent, dark brown to black, coriaceous, periphyses absent, short papillate, ostiolate, hyphae-like setae arise from apical and basal parts of ascomata. Peridium one-layered, composed of hyaline to dark brown layers of irregular to polygonal thick-walled cells of textura angularis. Hamathecium composed of cellular pseudoparaphyses, septate, anastomosing above the asci. Asci 8-spored, thickwalled, bitunicate, fissitunicate, cylindrical to clavate, with a short, thick, furcate pedicel and with an apical chamber. Ascospores uniseriate to biseriate, broadly fusiform with narrowly rounded ends, straight to slightly curved, hyaline, thick-walled, transverse septate, phragmosporous, slightly constricted at the median septum, the upper half broader than the lower one, rough-walled, slightly verruculose. Asexual morph: Undetermined.

Etymology In honor of Drs. Seshagiri Raghukumar and Chandralatha Raghukumar for their contributions to marine mycology.

Type species Raghukumaria keshaphalae Devadatha, V.V Sarma et E.B.G Jones, sp. nov.

\section{Raghukumaria keshaphalae Devadatha, V.V Sarma et E.B.G Jones, sp. nov. (Figures 5A-N and 6)}

(MycoBank MB 829063) Sexual morph. Ascomata 175$470 \mu \mathrm{m}$ high, $125-410 \mu \mathrm{m}$ diam. $(\overline{\mathrm{x}}=293 \times 234 \mu \mathrm{m}, \mathrm{n}=5)$, Immersed, to erumpent, globose to oval, black, dark brown to black, coriaceous; without periphyses, ostiolate, short papillate (Figure 5A-C), covered by hyphae-like setae rising from apical and basal parts of the ascomata (Figure 5G). Ostiole 80-150 $\mu \mathrm{m}$ long, 30-100 $\mu \mathrm{m}$ diam. $(\overline{\mathrm{x}}=112 \times 57 \mu \mathrm{m}, \mathrm{n}=5)$, lacking periphyses (Figure $5 \mathrm{C}$ ). Peridium 10-30 $\mu \mathrm{m}$ thick, one-layered, composed of 5-6 hyaline to dark brown layers of irregular to polygonal thick-walled cells of textura angularis (Figure 5D). Hamathecium composed of 1.5-2 $\mu \mathrm{m}$ diam., unbranched, septate, cellular pseudoparaphyses, and anastomosing above the asci (Figure 5E-F). Asci $80-175 \times 10-20 \mu \mathrm{m}$ $(\overline{\mathrm{x}}=125 \times 14 \mu \mathrm{m}, \mathrm{n}=20), 8$-spored, thick-walled, bitunicate, fissitunicate, cylindrical to clavate, with a short, thick basal, furcate pedicel and an apical ocular chamber (Figure $5 \mathrm{H}-\mathrm{M})$. Ascospores 22-30 $\times 6-10 \mu \mathrm{m}(\overline{\mathrm{x}}=25 \times 8 \mu \mathrm{m}$, $\mathrm{n}=50$ ), uni- to biseriate, broadly fusiform with narrowly rounded ends, straight to slightly curved, hyaline, fusiform, 3-5 transverse septate, thick-walled, slightly constricted at the median septum, upper half broader than lower one, rough-walled, slightly verruculose, lacking globules, appendages or gelatinous sheaths (Figure 5NU). Asexual morph: Undetermined.

Etymology Keshaphalae from Sanskrit, in reference to fruit body covered with hyphae-like setae (kesha means hairs, phalae refers to fruit bodies in Sanskrit).

\section{Known geographical distribution India.}

Material examined India, Tamil Nadu, Tiruvarur, Muthupet mangroves, on decayed wood of Aegiceras cormicualtum (L.) Blanco (Primulaceae), $\left(10.4^{\circ} \mathrm{N}, 79.5^{\circ} \mathrm{E}\right), 24$ th December 2016, B. Devadatha, holotype: AMH-10020, ex-type living culture $=$ NFCCI-4522.

Notes: Multigene phylogeny inferred from a combined nuclear LSU, SSU, TEF-1 $\alpha$, ITS and RPB2 genes revealed that Raghukumaria keshaphalae grouped within Trematosphaeriaceae with significant support from ML 99\%, MP 99\% 1.00 BIPP (Figure 6). Raghukumaria keshaphalae is comparable to Halomassarina and Falciformispora in having aggregate, erumpent, globose to ovoid, brown to black, short papillate ascomata, hamathecium containing cellular pseudoparaphyses, and ascospores that are hyaline, fusiform and transversely septate (Suetrong et al. 2009, 2011). Raghukumaria is distinguishable from Halomassarina and Falciformispora in having immersed ascomata, without clypeus and periphyses, covered by hyphae-like setae, and ascospores that are broadly fusiform with narrowly rounded ends, rough-walled slightly verruculose and lack globules, appendages or gelatinous sheaths. Halomassarina differs from Raghukumaria in producing ascomata under a clypeus and ascospores that are ellipsoidal, 1-3-trans-septate and surrounded by a 

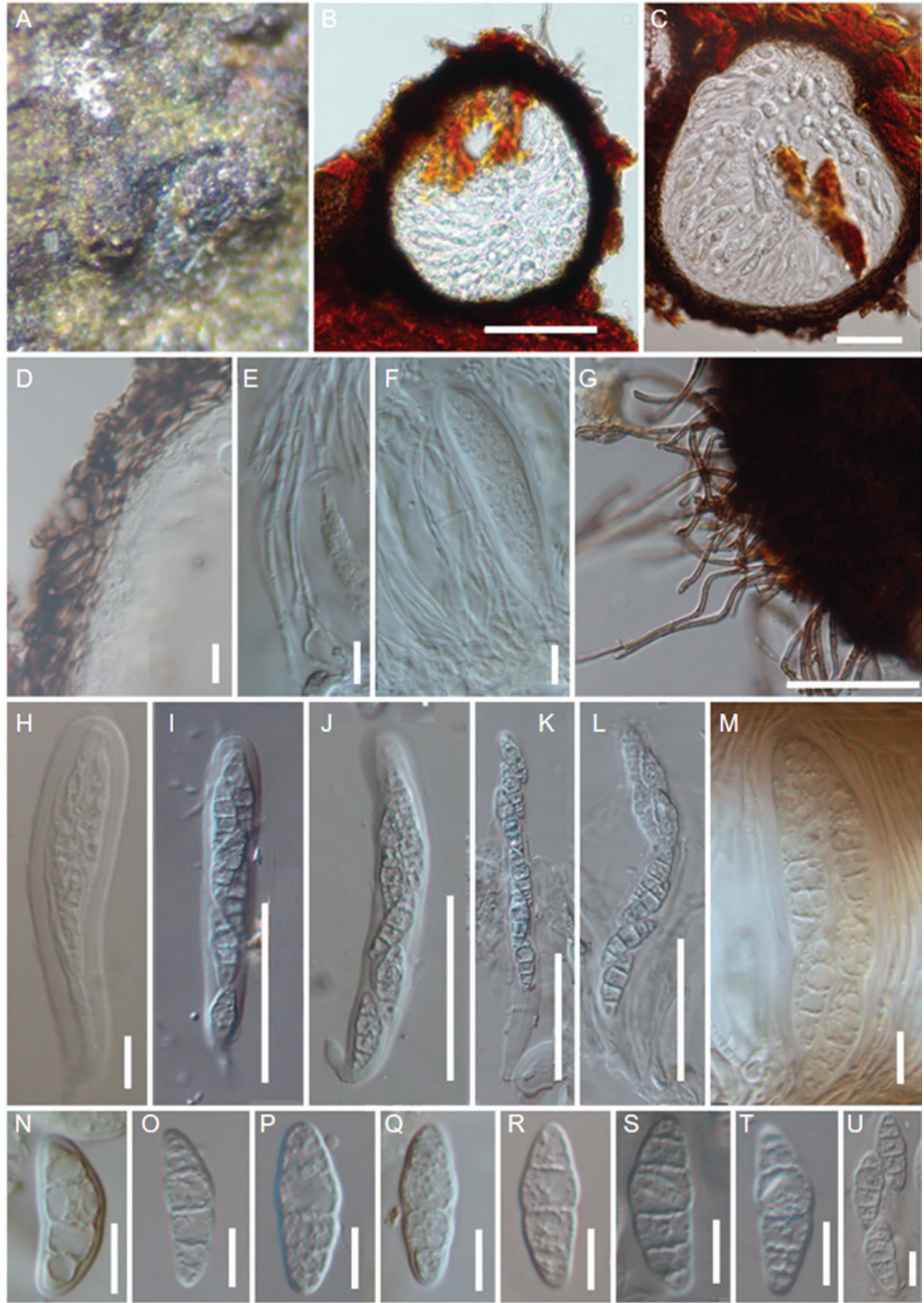

Figure 5: Raghukumaria keshaphalae (AMH 10020, holotype).

(A) Ascomata immersed in the decaying wood of Aegiceras corniculatum. (B-C) Longitudinal sections of ascomata. (D) Section of peridium. (E-F) Hamathecium of cellular pseudoparaphyses. (G) Hyphae-like setae. (H-M) Immature and mature asci. (N-U) Hyaline ascospores. Scale bars: $\mathrm{B}=10 \mu \mathrm{m} ; \mathrm{C}, \mathrm{G}, \mathrm{I}-\mathrm{L}=50 \mu \mathrm{m} ; \mathrm{D}-\mathrm{F}, \mathrm{H}, \mathrm{M}-\mathrm{U}=10 \mu \mathrm{m}$. 


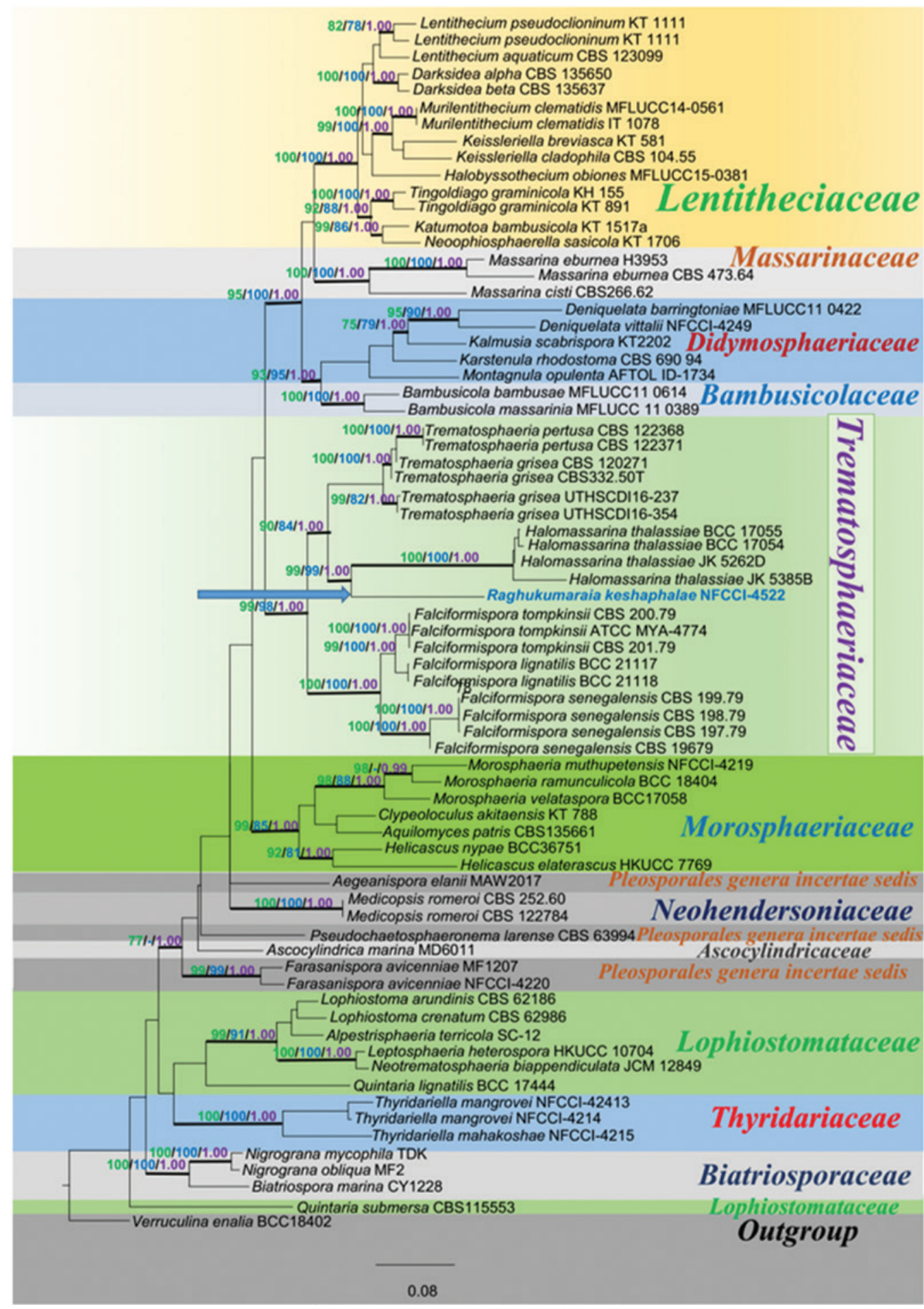

Figure 6: The combined LSU, SSU rDNA, TEF-1 $\alpha$, ITS and RPB2 gene datasets, comprising 72 taxa including genera from 11 families belonging to Pleosporales, were analyzed with Verruculina enalia Kohlm. et Volkm.-Kohlm as the outgroup.

Randomized axelerated maximum likelihood (RAxML) analysis of the combined dataset yielded the best tree with a final maximum likelihood (ML) optimization likelihood value of $-46,099.170674$. The matrix had 2283 distinct alignment patterns, with $30.40 \%$ of undetermined characters or gaps. The maximum parsimonious data matrix of the combined dataset comprised 71 in-group taxa and one outgroup taxon with 4466 characters, of which 2333 were constant, 1538 parsimony-informative (34.4\%) and 595 parsimony-uninformative. The parsimony analyses of the data matrix yielded 36 equally most parsimonious trees with a tree length of 9051 steps (consistency index $[\mathrm{Cl}]=0.387$, retention index $[R I]=0.610$, rescaled consistency index $[R C]=0.236$, homoplasy index $[H I]=0.613$ ) in the first tree. Phylogenetic trees obtained from ML, maximum parsimony (MP) and Bayesian inference were similar in topology and congruent with earlier studies (Suetrong et al. 2011, Hyde et al. 2013). Branches with Bayesian inference posterior probabilities (BIPP) from Markov chain Monte Carlo (MCMC) analysis equal or greater than 0.95 are in bold. 
gelatinous sheath (Suetrong etal.2009). In addition to this, a comparison of LSU nucleotides between $R$. keshaphalae and Halomassarina thalassiae (GenBank: GQ925843) revealed a $9.4 \%$ (82 nucleotides) difference, which confirms its placement as a separate genus but within Trematosphaeriaceae. Falciformispora is markedly different from Raghukumaria in having broadly clavate to fusoid asci, ascospores that are smooth-walled, 6-7 transverse septate (vs. 3-5 septate in Raghukumaria), surrounded by a thin gelatinous sheath and a single scythe-like appendage at the terminal end (Hyde 1992). Trematosphaeria and Raghukumaria share overlapping characters of ascomata and asci. However, Trematosphaeria lacks hyphaelike setae on the ascomata but has brown to dark brown ascospores when compared to Raghukumaria (Suetrong et al. 2011). Such a close affinity could be inferred from the phylogram where Raghukumaria formed a basal clade to Halomassarina and Trematosphaeria with strong bootstrap support from ML 99\%, MP 99\% 1.00 BIPP (Figure 6).

Quintaria Kohlm. et Volkm.-Kohlm., a polyphyletic genus, resembles Raghukumaria in having hyaline, fusiform, transverse septate ascospores lacking a sheath and appendages. However, Quintaria is distinct from Raghukumaria in having completely immersed, obpyriform, carbonaceous ascomata with black incrustations lining the sides of the ascomata while Raghukumaria has erumpent, coriaceous, short papillate ascomata surrounded by hyphae-like setae (Kohlmeyer and Volkmann-Kohlmeyer 1991, Jones et al. 2009). Morosphaeria Suetrong, Sakay., E.B.G. Jones et C.L. Schoch is obviously different from Raghukumaria in having subglobose to lenticular ascomata and fusiform to ellipsoidal ascospores, covered by a thick gelatinous sheath (Suetrong et al. 2009). Farasanispora Abdel-Wahab, Bahkali et E.B.G. Jones and Raghukumaria also share common characters such as ascomata that are immersed to erumpent and hyaline, fusiform, trans-septate ascospores ( $\mathrm{Li}$ et al. 2016). However, the former is distinct from the latter genus in having smaller ascomata, a clypeus and periphyses in the ostiolar canal and septate ascospores at maturity and its phylogenetic position is uncertain (Li et al. 2016, Devadatha et al. 2018). Based on the unique morphological characteristics and phylogenetic relationships discussed above, when compared to other existing genera, we, herein, introduce Raghukumaria as a new genus, typified by Raghukumaria keshaphalae under the family Trematosphaeriaceae (Figures 5 and 6).

Sordariomycetes O.E. Erikss. et Winka, Myconet 1: 10 (1997).
The class comprises 28 orders, 90 families and 1344 genera and is one of the largest in the Ascomycota (Maharachchikumbura et al. 2015, Hongsanan et al. 2017).

Coniochaetales Huhndorf, A.N. Mill. et F.A. Fernández, Mycologia 96 (2): 378 (2004) (Sordariomycetidae).

Huhndorf et al. (2004) proposed this monotypic order Coniochaetales to accommodate Coniochaetaceae which earlier belonged to the order Sordariales (Checa et al. 1988, Kirk et al. 2001, Eriksson et al. 2004).

Coniochaetaceae Malloch et Cain, Canadian Journal of Botany 49 (6): 878 (1971).

The family Coniochaetaceae comprises two genera, Barrina A.W. Ramaley and Coniochaeta (Sacc.) Cooke. Species belonging to Coniochaetaceae are worldwide in distribution and exhibit different modes of nutrition (Samarakoon et al. 2018). They can be saprobes on dung, plant litter or in soil, strongly acidic water with high heavy metal concentrations and food, or pathogenic on plants or animals, but rarely in humans (Weber 2002, Weber et al. 2002, Huhndorf et al. 2004, García et al. 2006, Kirk et al. 2008, Damm et al. 2010, Khan et al. 2013, Troy et al. 2013, Miller et al. 2014, Vázquez-Campos et al. 2014, Maharachchikumbura et al. 2015, 2016, Wijayawardene et al. 2017, Wanasinghe et al. 2018).

Coniochaeta (Sacc.) Massee, Grevillea 16 (77): 16 (1887). The genus Coniochaeta is typified by Coniochaeta ligniaria (Grev.) Massee and is characterized by dark brown to black, solitary or aggregated, typically setose, pyriform to globose ascomata with or without ostioles. The peridium is membranaceous to pseudoparenchymatous, or rarely coriaceous (Samarakoon et al. 2018). A paraphysate hamathecium is present or absent. Asci are unitunicate and thin-walled, with a small non-amyloid apical ring and ascospores are one-celled, usually dark brown and often laterally compressed with a germ slit (Weber 2002, Asgari et al. 2007). Their hyphomycetous asexual morph is characterized by phialidic conidiogenous cells previously described in Lecythophora (Weber 2002, Khan et al. 2013). There are 95 validly published Coniochaeta names in Index Fungorum (accessed in 21 January 2019).

\section{Coniochaeta marina Dayarathne, S. Tibell, Tibell, et K.D. Hyde, sp. nov. (Figures 7A-P and 8)}

(MycoBank MB829575) Saprobic on driftwood retrieved from thesea.Sexualmorph:Ascomata230-275 $\times 220-240 \mu \mathrm{m}$ 

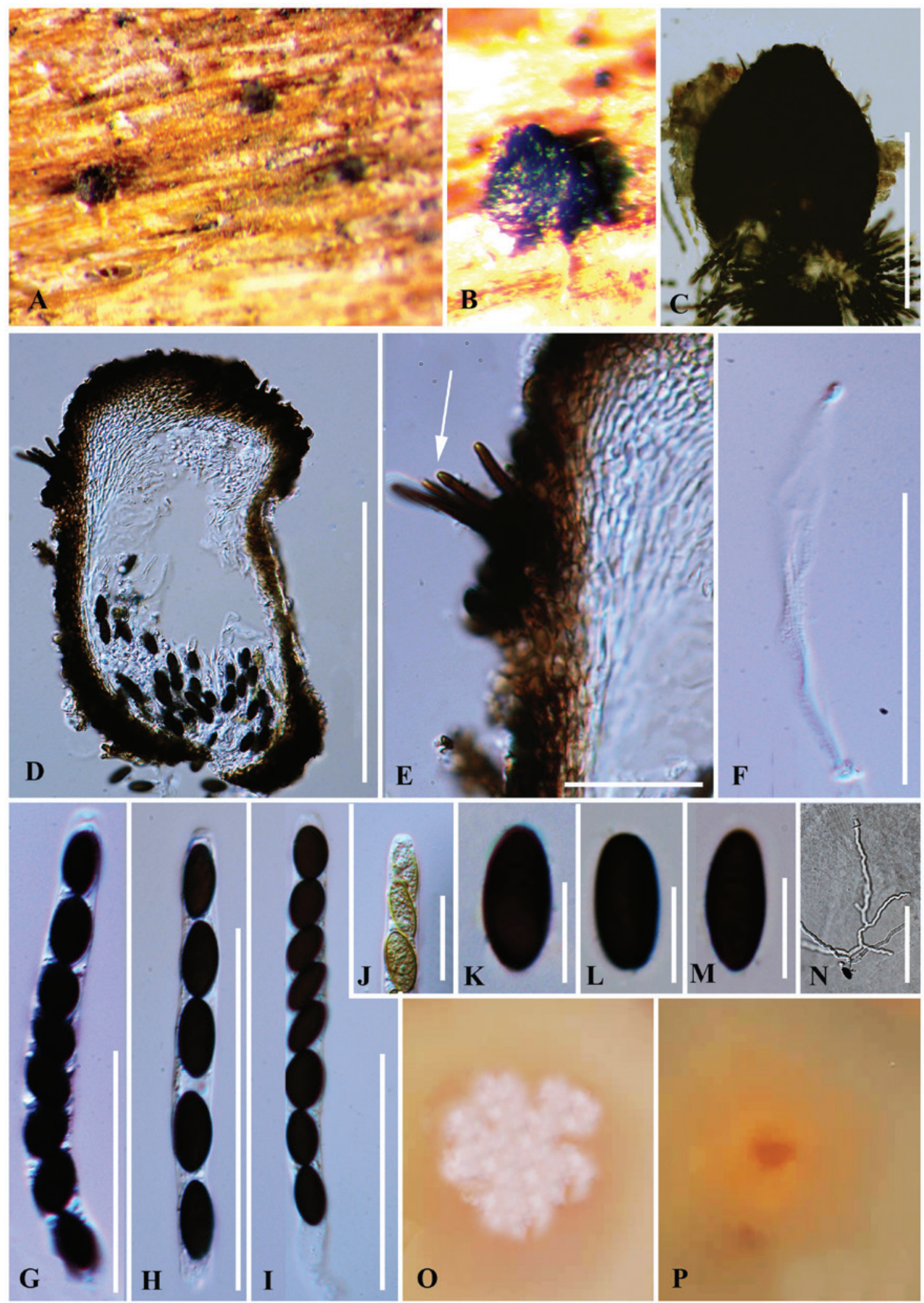

Figure 7: Coniochaeta marina (MFLU 17-2653, holotype, sexual morph).

(A-C) Appearance of ascomata on host. (D) Section through ascoma. (E) Peridium (arrowed - short setae). (F) Paraphyses. (G-I) Asci. (J) Small apical apparatus of an immature asci. (K-M) Ascospores. (N) Germinating ascospore. (O, P) Upper and bottom view of colony on agar plate. Scale bars: $C-D=200 \mu \mathrm{m} ; \mathrm{G}, \mathrm{I}=100 \mu \mathrm{m} ; \mathrm{E}, \mathrm{J}, \mathrm{N}=20 \mu \mathrm{m} ; \mathrm{F}, \mathrm{H}=50 \mu \mathrm{m} ; \mathrm{I}-\mathrm{K}=10 \mu \mathrm{m}$. 


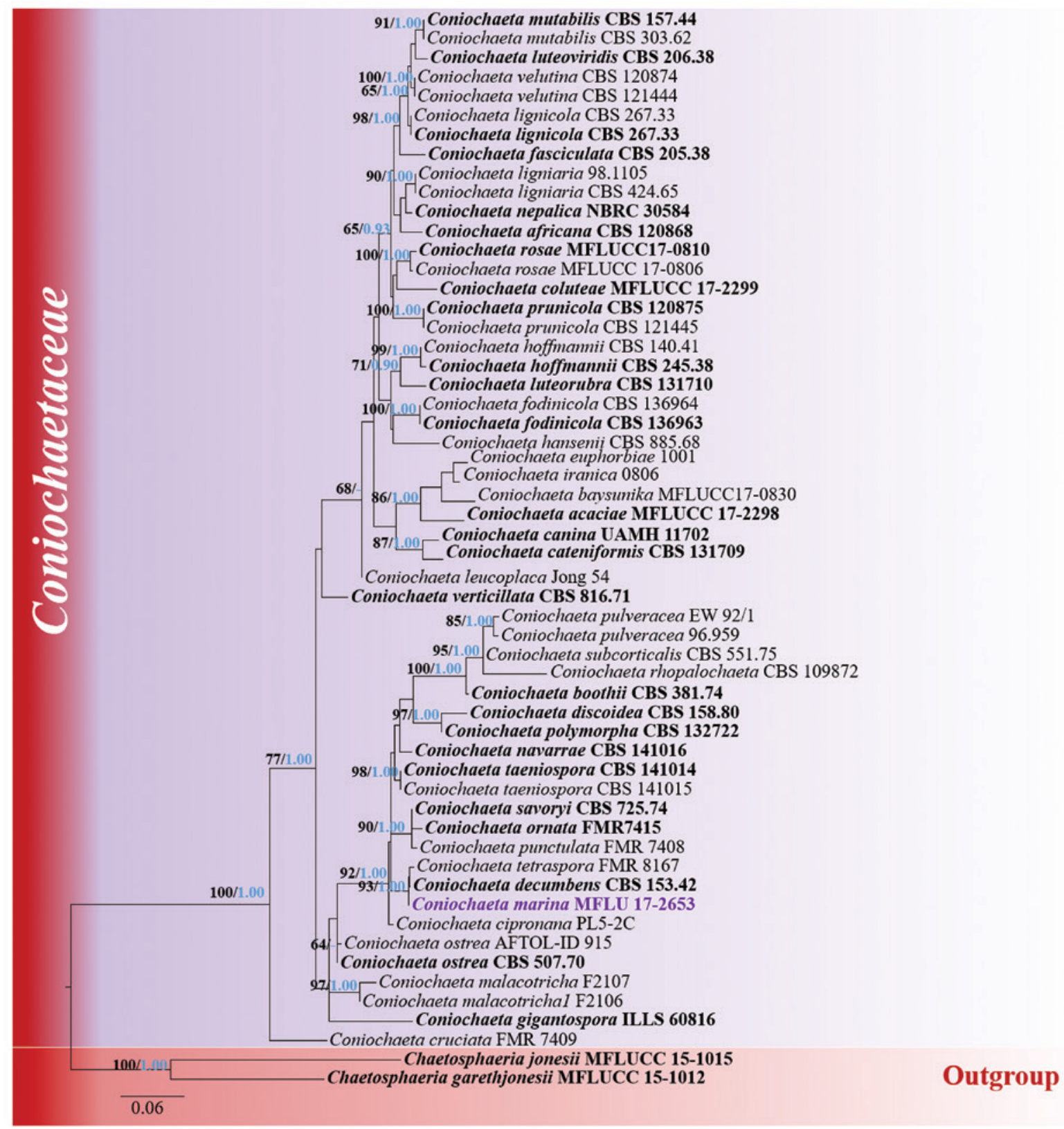

Figure 8: Phylogram generated from maximum likelihood analysis based on combined partial LSU and ITS rDNA sequence data. Bootstrap support values equal or greater than 65 for maximum likelihood (ML) (black) and Bayesian inference posterior probability (BIPP) (blue) equal to or greater than 0.90 are given above the nodes. We could not obtain a stable phylogeny for the maximum parsimony (MP) analyses that was compatible with the ML and MB topology. The newly generated sequence is in purple.

$(\overline{\mathrm{x}}=253 \times 235 \mu \mathrm{m}, \mathrm{n}=5)$, perithecial, solitary to gregarious, non-stromatic, semi-immersed to superficial, globose to ovoid, ostiolate, but without distinct neck region, with setae $12-18 \times 2-2.8 \mu \mathrm{m}$, that are unbranched, smooth, gradually tapering to round tips. Ostiole central, papillate, with circular outline, lacking periphyses, filled with hyaline cells. Peridium $22-40 \mu \mathrm{m}$ wide, brittle when dry, soft when rehydrated, two-layered. Inner layer consisting of hyaline to subhyaline, strongly compressed cells, outer layer consisting of densely packed, moderately thickwalled, brown cells of textura prismatica, darker towards outside. Paraphyses numerous, 2-3 $\mu \mathrm{m}$ wide, filamentous, septate. Asci $100-115 \times 6-8 \mu \mathrm{m} \quad(\overline{\mathrm{x}}=112 \times 7.5 \mu \mathrm{m}$, $\mathrm{n}=30$ ), 8-spored, with short stipe, with a J-small apical apparatus. Ascospores $12-16 \times 4.5-6.5 \mu \mathrm{m}(\overline{\mathrm{x}}=14 \times 6 \mu \mathrm{m}$, $\mathrm{n}=30$ ), overlapping uniseriate, ellipsoid, slightly laterally 
compressed, hyaline at first, becoming olivaceous-brown and finally dark brown and opaque, darker in $3 \% \mathrm{KOH}$, aseptate, with a conspicuous, straight germ slit across the entire length, smooth, without sheath or appendages. Asexual morph: Undetermined.

Culture characteristics: colonies on MEA (with freshwater), reaching $25-35 \mathrm{~mm}$ diam. after 4 weeks at $25^{\circ} \mathrm{C}$, pinkish white, dense, immersed mycelia, effuse, with white hyphal stands towards the center, rough surface towards center, diffuse margin; reverse orangish edges, orangish white at the center, radiating, effuse and zonate.

Etymology Reflects the known habitat of the taxon.

Known geographical distribution West and East Coast of Sweden.

Material examined SWEDEN, Bohuslän. Skaftö par., Fiskebäckskil, Rödbergsviken, $58^{\circ} 15^{\prime} 08^{\prime \prime}$; $11^{\circ} 27^{\prime} 58^{\prime \prime}$, on a large piece of driftwood retrieved from the sea, Leif Tibell, June 2017, GJ 393 (MFLU 17-2653 holotype) ex-type culture MFLUCC 18-0408; Uppland. Väddö par., Nothamn, on driftwood, Sanja Tibell, August 2018, ST18-54, 18-55 (UPS). GenBank numbers ITS $=$ MK458764, LSU $=$ MK458765.

Note: Figure 8 shows the phylogram generated from maximum likelihood analysis based on combined partial LSU and ITS rDNA sequence data. Related sequences were obtained following Wanasinghe et al. (2017, 2018). Fifty-six strains were included in the combined LSU and ITS sequence analyses, which comprised 1585 characters with gaps (933 for LSU and 652 for ITS). Single gene analyses were carried out and all were compatible in topology to the combined tree. Chaetosphaeria jonesii and C. garethjonesii strains (MFLUCC 15-1015, MFLUCC 15-1012) (Chaetosphaeriaceae) were used as the outgroup taxa. Tree topology of the maximum-likelihood analysis was similar to that of the Bayesian analysis. The best scoring RAxML tree with a final likelihood value of -9044.907024 is presented. The matrix had 657 distinct alignment patterns, with $53.22 \%$ of undetermined characters or gaps. Estimated base frequencies were as follows; $A=0.249726$, $\mathrm{C}=0.237909, \mathrm{G}=0.289551, \mathrm{~T}=0.222813$; substitution rates $\mathrm{AC}=1.128560, \mathrm{AG}=1.643715, \mathrm{AT}=0.937739, \mathrm{CG}=1.424143$, $\mathrm{CT}=5.504308, \mathrm{GT}=1.000000$; gamma distribution shape parameter $\alpha=0.315444$.

Phylogenetic results showed that the novel taxon Coniochaeta marina (MFLU 17-2653) grouped as a basal lineage in a subclade comprising Coniochaeta tetraspora (FMR 8167) and Coniochaeta decumbens (CBS 153.42) with high statistical support (93\% ML, 1.00
PP) (Figure 8). Further, the base pair differences of $C$. marina to $C$. decumbens and $C$. tetraspora for LSU are 2 bp (out of 570) and $1 \mathrm{bp}$ (out of 570), respectively. ITS base pair difference of $C$. marina to $C$. decumbens is 3 bp (out of 481) while ITS data is not available for $C$. tetraspora. The new taxon best fits the genus Coniochaeta by having dark brown to black, solitary or aggregated, typically setose, pyriform to globose ascomata with an ostiole, membranaceous to pseudoparenchymatous peridium, paraphysate hamathecium, unitunicate, thin-walled asci with a small non-amyloid apical ring and one-celled, dark brown ascospores (Weber 2002, Asgari et al. 2007, Samarakoon et al. 2018). Coniochaeta marina showed close phylogenetic affinities to $C$. tetraspora and C. decumbens. However, $C$. tetraspora can be clearly distinguished from $C$. marina mainly by having 4-spored asci. Further, asci of $C$. marina are longer and narrower than those of $C$. tetraspora $(100-115 \times 6-8$ vs. 50-55 $\times 8-11 \mu \mathrm{m})$ (Cain 1961). Coniochaeta decumbens is an asexual morph whose sexual morph is undetermined. However, colony color of $C$. decumbens is olivaceous-brown (Perdomo et al. 2013) while colony color of $C$. marina is pinkish white. Hence, based on concatenated LSU and ITS gene analyses, along with morphological characteristics, we establish this taxon as a novel species of Coniochaeta.

Hypocreales Lindau, Natürl. Pflanzenfam.: 343 (1897) (Hypocreomycetidae).

An order comprising nine families with a worldwide distribution (Wijayawardene et al. 2018).

Nectriaceae Tul. et C. Tul., Selecta Fungorum Carpologia: Nectriei- Phacidiei- Pezizei 3: 3 (1865).

Nectriaceae comprises some 63 genera but only a few are marine (Jones et al. 2015, Wijayawardene et al. 2018).

Fusicolla Bonord., Handbuch der allgemeinen Mykologie: 150 (1851).

The genus Fusicolla was introduced by Bonorden (1851) with Fusicolla betae (Desm.) Bonord., as the type species and currently accommodates 18 species (Index Fungorum).

\section{Fusicolla bharatavarshae Devadatha, V.V Sarma et E.B.G Jones, sp. nov (Figures 9A-N, 10 and 11A-P)}

(MycoBank MB 828607) Saprobic on decayed wood of Avicennia marina (Forssk.) Vireh. Sexual morph: Ascomata 

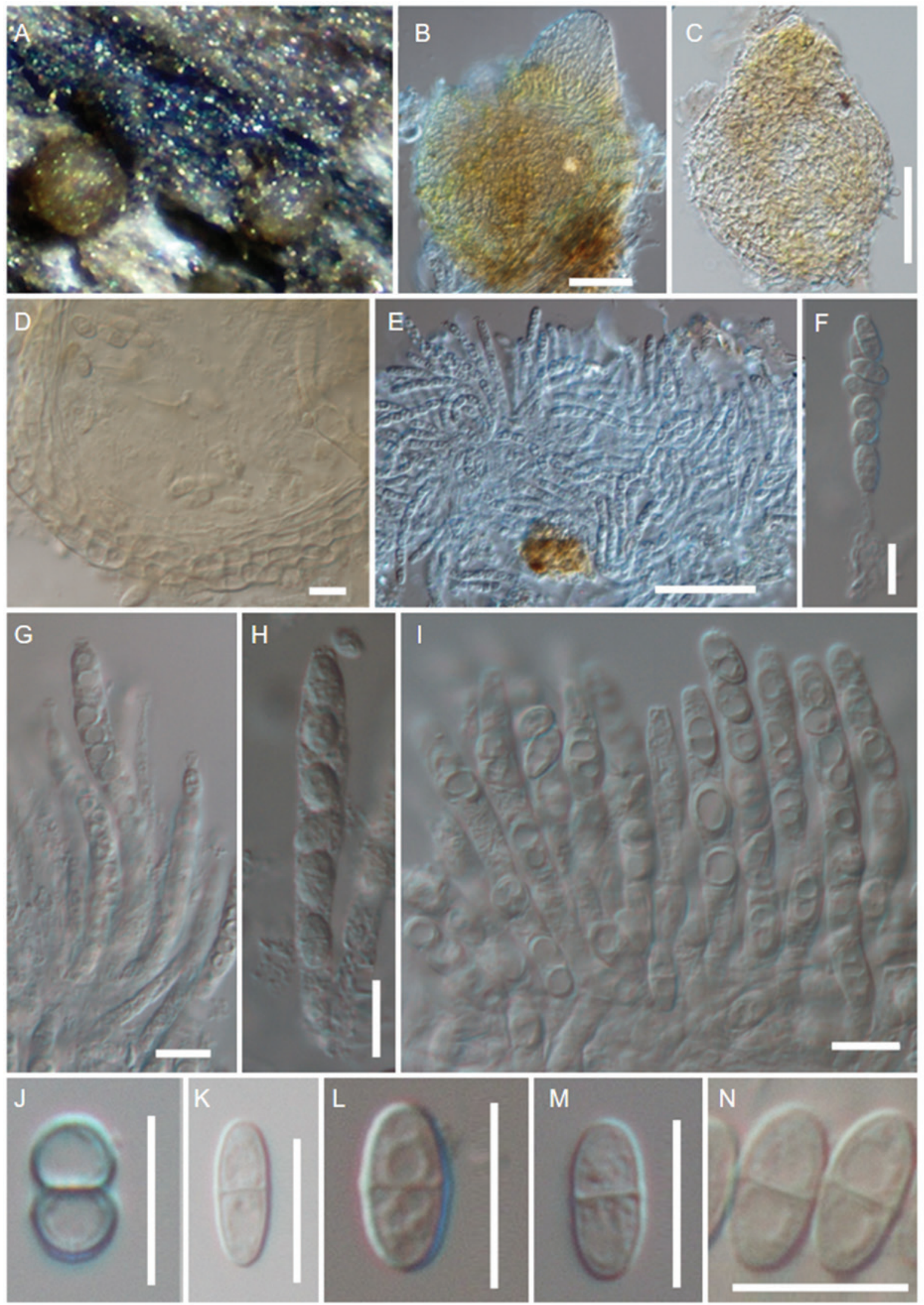

Figure 9: Fusicolla bharatavarshae (sexual morph, holotype).

(A) Ascomata superficial to semi-immersed on dead wood of Avicennia marina. (B-C) Ascomata. (D) Section of peridium. (E-I) Immature and mature asci. (J-N) Ascospores. Scale bars: $(B-C, E)=50 \mu \mathrm{m} ;(D, F-N)=10 \mu \mathrm{m}$. 


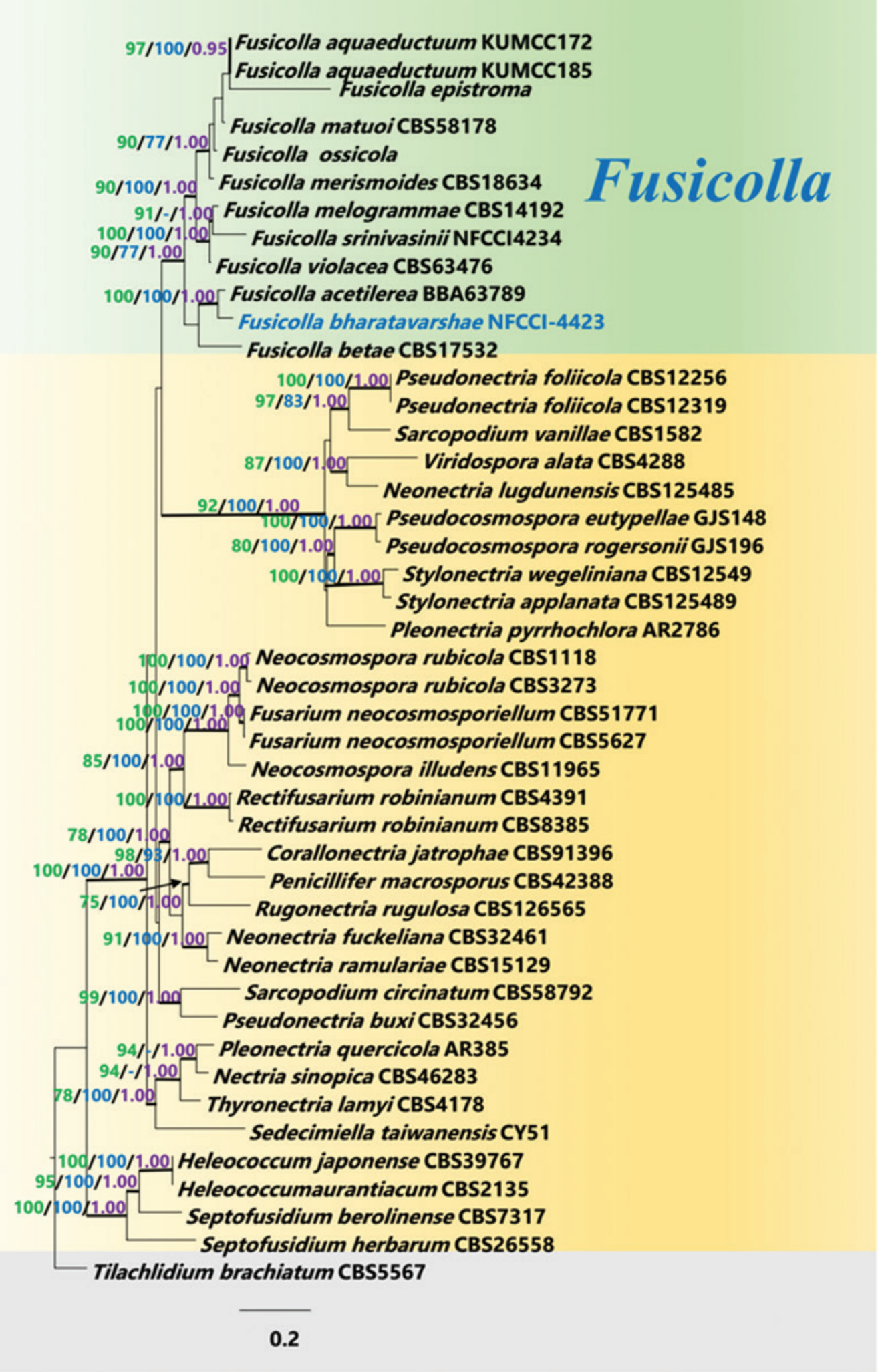

Figure 10: Randomized axelerated maximum likelihood (RAxML) tree based on combined LSU rDNA, ITS, $\beta$-tubulin and RPB2 gene regions of Nectriaceae and related taxa.

Bootstrap support values for maximum likelihood, maximum parsimony $(>75 \%)$ and Bayesian inference posterior probability values ( $>0.95 \%)$, respectively, are given above each branch. The new species is indicated in blue. The tree was rooted to Tilachlidium brachiatum (Batsch) Petch (Tilachlidiaceae). Branches with Bayesian inference posterior probabilities (BIPP) from Markov chain Monte Carlo (MCMC) analysis equal or greater than 0.95 are in bold. 

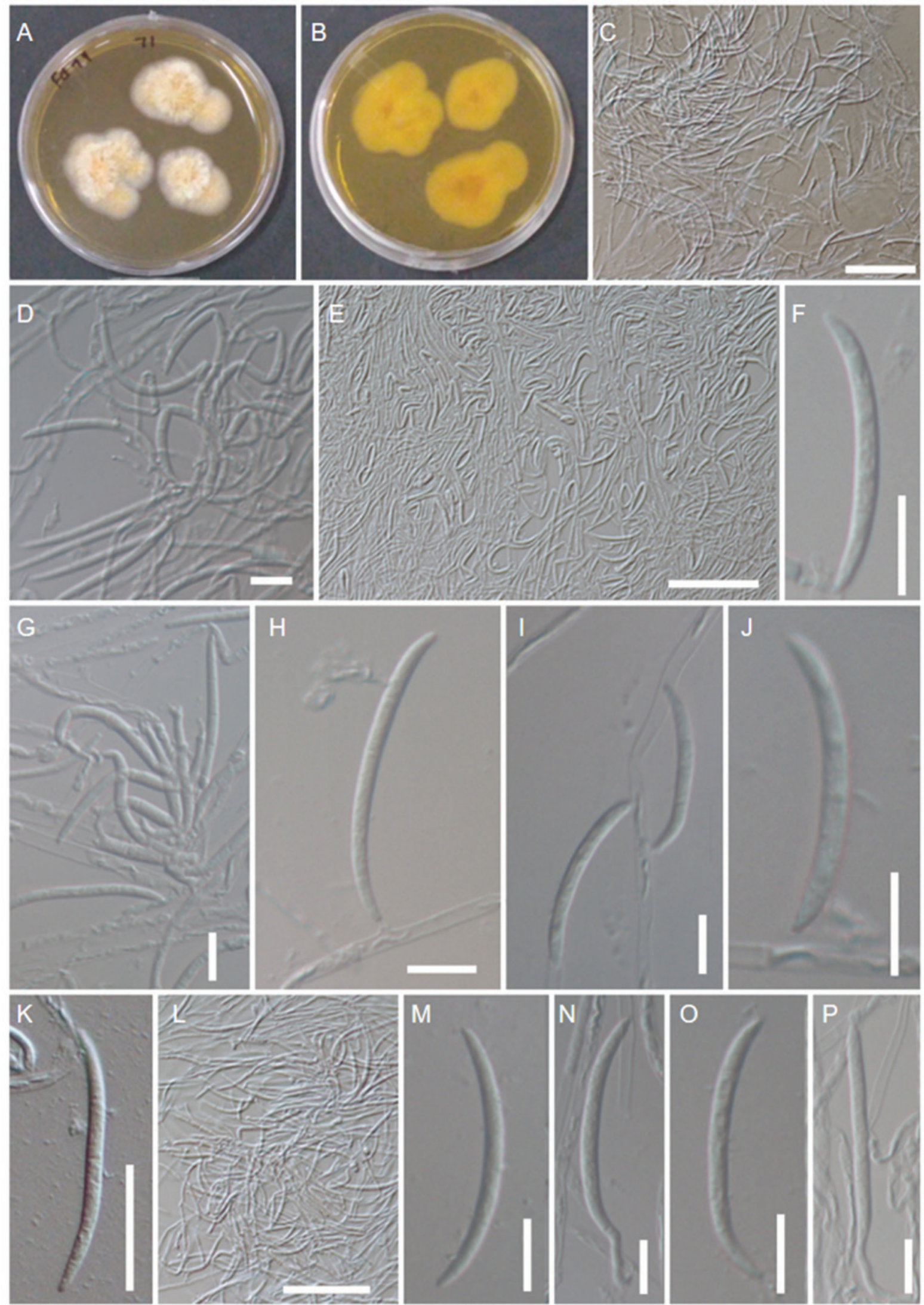

Figure 11: Fusicolla bharatavarshae (asexual morph).

(A-B) Colonies on malt extract agar after 7 days. (C, E, F, H-P) Conidia. (D, G) Conidiophores. Scale bars: (C, E, K-L) =50 $\mu \mathrm{m} ;(\mathrm{D}, \mathrm{F}, \mathrm{J}, \mathrm{M}-\mathrm{P})=10 \mu \mathrm{m}$. 
205-275 $\mu \mathrm{m}$ high, $170-580 \mu \mathrm{m}$ wide $(\overline{\mathrm{x}}=246 \times 243 \mu \mathrm{m}$, $\mathrm{n}=8$ ), perithecial, superficial, solitary to gregarious, non-stromatic, globose to sub-globose, coriaceous pale yellow to pale orange, not developing color in 3\% $\mathrm{KOH}$, turning orange in lactic acid, ostiolate (Figure 9A-C). Ostiole short $55-90 \times 60-80 \mu \mathrm{m}(\overline{\mathrm{x}}=64 \times 6 \mu \mathrm{m}, \mathrm{n}=8)$. Peridium 15-20 $\mu \mathrm{m}(\overline{\mathrm{x}}=18, \mathrm{n}=8)$, thick, dark-colored, two-layered, outer layer of 3-4 rows of cells of textura angularis, inner layer of 3-6 rows of elongate and hyaline cells. Paraphyses 1-2 $\mu \mathrm{m}$, interspersed with asci, deliquescent, moniliform (Figure 9G). Asci 55-65 $\times 5-9 \mu \mathrm{m}$ $(\overline{\mathrm{x}}=61 \times 6 \mu \mathrm{m}, \mathrm{n}=20)$, unitunicate, cylindrical to narrowly clavate, short pedunculate, thin-walled, 8 -spored, uniseriate, persistent, apically truncate when immature, with a faint apical ring-like thickening (Figure 9F-I). Ascospores $7-12 \times 2-5 \mu \mathrm{m}(\overline{\mathrm{x}}=8 \times 3 \mu \mathrm{m}, \mathrm{n}=50)$, ellipsoidal, rounded at ends, 1-septate, hyaline, slightly constricted at the septum when young, rough walled, without appendage or sheath (Figure 9J-N).

Asexual morph: Fusarium-like. Colonies on MEA 30-40 mm in diam., slimy, white to orange in center, white at margin, and white to cream in reverse, fast growing, filamentous, raised, lobate, and irregular (Figure 11A-B). Mycelium 1-3 $\mu \mathrm{m}$ diam., superficial, septate, branched, hyaline hyphae, micro conidia absent, macro conidia 30-48 $\times 2-3 \mu \mathrm{m}(\overline{\mathrm{x}}=41 \times 2.5 \mu \mathrm{m}, \mathrm{n}=50)$, hyaline, smooth, 0-4-septate, long fusiform, falcate, acute at both ends (Figure 11C-P).

Etymology Specific epithet refers to the name of the country Bharat (India), an alternative official name of India.

\section{Known geographical distribution India.}

Material examined India, Tamil Nadu, Tiruvarur, Muthupet mangroves, on decayed wood of Avicennia marina $\left(10.4^{\circ} \mathrm{N} 79.5^{\circ} \mathrm{E}\right), 28$ th November 2015, B. Devadatha, AMH-9910 (holotype), ex-type living culture =NFCCI4423. GenBank numbers ITS=MK152510, LSU=MK152511, SSU $=$ MK152532, RPB2 $=$ MK157022, TUB2 $=$ MK376462.

Habitat On decayed wood of Avicennia marina in mangroves.

Notes: The genus Fusicolla was typified by Fusicolla betae and includes nine accepted species (Index Fungorum 2018). Fusicolla ossicola Lechat et Rossman, Fusicolla aquaeductuum (Radlk. et Rabenh.) Gräfenhan, Seifert et Schroers and Fusicolla melogrammae Lechat et Aplin were reported to have both sexual and asexual stages while other species exist as asexual morphs (Gräfenhan et al. 2011). Fusicolla bharatavarshae shares morphologically similar characters to the genus, such as superficial, non-stromatic, globose to sub-globose, pale yellow to pale orange ascomata, lacking reaction to $\mathrm{KOH}$, ascospores that are 1-septate, becoming orange in lactic acid, ellipsoidal, hyaline and straight or slightly curved. It has a Fusarium-like asexual morph with fusiform conidia along with $F$. ossicola, F. aquaeductuum and F. melogrammae which were reported as holomorphs (Figures 9 and 11). However, $F$. bharatavarshae differs from other Fusicolla species in having shorter asci, ascospores that are hyaline, slightly constricted at the septum when young, rough-walled, a different colony morphology and in its occurrence on mangrove wood. Fusicolla ossicola is distinct from F. bharatavarshae in having longer asci $(80-85 \times 8-11$ $\mu \mathrm{m}$ vs. $55-65 \times 5-9 \mu \mathrm{m}$ ), pale golden brown, spinulose ascospores that are $0-3$-septate, shorter macro conidia (12-28 $\times 3-3.5 \mu \mathrm{m}$ vs. 30-48×2-3) (Lechat and Rossman 2017). Fusicolla melogrammae can be distinguished from F. bharatavarshae as it has longer asci $(70-80 \times 10-12 \mu \mathrm{m}$ vs. $55-65 \times 5-9 \mu \mathrm{m})$, hyaline to pale golden brown, spinulose, longer ascospores $(12-14 \times 4.5-5 \mu \mathrm{m}$ vs. $7-12 \times 2-5$ $\mu \mathrm{m})$ that are 0-3-septate, and shorter, fusiform macro conidia (30-38 ×4.5-5.5 $\mu \mathrm{m}$ vs. 30-48 $\times 2-3$ ) (Crous et al. 2016). Both $F$. aquaeductuum and $F$. bharatavarshae are similar in having overlapping dimensions of ascomata, asci and ascospores. But the former species is characterized by the presence of ascospores that are ellipsoid to oval, 1-septate, slightly contracted at septum, smooth at maturity and shorter macro conidia $(20-30 \times 2-5 \mu \mathrm{m}$ vs. $30-48 \times 2-3 \mu \mathrm{m}$ ) in contrast to the latter species (Huang et al. 2018). Whereas Fusicolla acetialriae (Tubaki, C. Booth et T. Harada) Gräfenhan et Seifert is different from F. bharatavarshae in lacking a sexual stage, even though both have fusarium-like asexual stages with overlapping conidial dimensions $(20-30 \times 2-5 \mu \mathrm{m}$ vs. $30-48 \times 2-3 \mu \mathrm{m})$ and straight or curved, long fusiform conidia. Also, $F$. bharatavarshae is different from $F$. acetialriae in having a faster growth on malt extract agar, slimy, white to orange in center, white at margin, and reverse with white to cream, lacking micro conidia, macro conidia 0-4septate, fusiform, falcate and acute at both ends. Fusicolla acetialriae is a slow grower; colony light brown or light yellow-brown at surface, with a sterile margin and reverse with vinaceous or brown-vinaceous pigmentation, and it produces both micro and macro conidia with 3(4) transverse septate and a rounded apex (Tubaki et al. 1976, Gerlach and Nirenberg 1982).

The combined LSU, ITS rDNA, $\beta$-tubulin and RPB2 gene datasets of 45 taxa with 3065 nucleotide characters 
belonging to Nectriaceae and closely related taxa with Tilachlidium brachiatum (Batsch) Petch as the outgroup were analyzed. RAxML analysis of the combined dataset yielded the best tree (Figure 10) with a final ML optimization likelihood value of -43649.829041 . The matrix had 2224 distinct alignment patterns, with $28.99 \%$ of undetermined characters or gaps. The maximum parsimonious data matrix of the combined dataset consisted of 45 taxa with 3065 characters, of which 1525 were constant, 1222 parsimony-informative (39.8\%) and 318 parsimonyuninformative. One most parsimonious tree was produced using a heuristic search with a tree length of 6794 steps $(\mathrm{CI}=0.408, \mathrm{RI}=0.611, \mathrm{RC}=0.249, \mathrm{HI}=0.592)$. Phylogenetic trees obtained from ML, MP and BIPP were similar in topology.

Phylogenetic results indicated that the novel taxon Fusicolla bharatavarshae clustered together with F. acetelariae and shared a sister relationship with Fusicolla betae in Fusicolla clade with strong bootstrap statistical support (100\% ML, 100\% MP, 1.00 BIPP) (Figure 10). A significant $2.5 \%$ (14) nucleotide differences across ITS region was observed between $F$. bharatavarshae and $F$. acetelariae which suggests that our taxon is distinct. Based on the distinct morphology, phylogenetic evidence, base pair differences and the habitat, we introduce $F$. bharatavarshae as a new species under Fusicolla.

Fusarium Link, Magazin der Gesellschaft Naturforschenden Freunde Berlin 3 (1): 10 (1809).

A wide spread genus with 925 names in MycoBank with taxa in terrestrial and aquatic habitats, and as saprobes, parasites and endophytes.

\section{Fusarium sedimenticola M.M. Wang, F. Liu et L. Cai, sp. nov. (Figures 12 and 13)}

(MycoBank MB 829284) Asexual morph. Colonies on potato dextrose agar (PDA) grown in the dark reaching 6.3-6.9 cm diam. after $7 \mathrm{~d}$ at $25^{\circ} \mathrm{C}$, crateriform with entire edge, aerial mycelia dense, white; reverse yellowish brown. Colonies on Oat Agar (OA) reaching 6.1-6.9 cm diam. after $7 \mathrm{~d}$ at $25^{\circ} \mathrm{C}$, crateriform, aerial mycelia dense, colony undulate edge, white; reverse yellowish brown. On Synthetic Nutrient poor Agar (SNA) 6.5-6.9 cm diam. in $7 \mathrm{~d}$ at $25^{\circ} \mathrm{C}$, flat with erose edge, aerial mycelia scant, white; reverse white. Pigment pale brown on PDA and OA, absent on SNA. Odor absent. Sporodochia straw colored, formed abundantly on the surface of the carnation leaves. Sporodochial phialides subulate to subcylindrical, $15.5-20.5 \times 2.5-3.5$ $\mu \mathrm{m}$ (av. \pm SD: $17.5 \pm 1.2 \times 3.2 \pm 0.4 \mu \mathrm{m})$, smooth- and thinwalled, often with a minute apical collarette. Macroconidia fusiform, with a gentle curvature and nearly parallel dorsiventral lines or an unequal curvature, 3-septate, hyaline, thin- and smooth-walled, 19-33× 3-5.5 $\mu \mathrm{m}$ (av. \pm SD: $26.8 \pm 2.5 \times 4.7 \pm 0.5 \mu \mathrm{m}$ ), apical cell blunt, sometimes with a globose cell in at the terminal position, basal cell barely notched. Conidiophores formed on the aerial mycelium, 50-150 $\mu \mathrm{m}$ tall, bearing terminal monophialides; phialides subcylindrical or subulate, smooth- and thin-walled, 13.5-25.5 ×2-2.5 $\mu \mathrm{m}$ (av. \pm SD: $20.6 \pm 3.5 \times 2.3 \pm 0.1 \mu \mathrm{m}$ ). Microconidia hyaline, clavate, oval or ellipsoidal, smooth- and thin-walled, 0-1septate, $6.5-12 \times 3.5-4.5 \mu \mathrm{m}$ (av. \pm SD: $8.7 \pm 1.4 \times 4 \pm 0.4$ $\mu \mathrm{m})$. Chlamydospores intercalary, globose, relatively thick-walled, hyaline, 0-septate, 6.5-8 $\mu \mathrm{m}$ diam. Sexual morph undetermined.

Etymology Named after the habitat of this species, deepsea sediment.

Type Southwest Indian Ocean, from deep-sea sediment (longitude 63.92E, latitude 27.77S, depth $3166 \mathrm{~m}$ ), 2014, collected by the Chinese research vessel Dayang Yihao (Ocean No. 1), 30I-SWIR-S003TVG01 (HAMS 248044 holotype (dried culture), ex-holotype living culture CGMCC 3.19499=LC12845). GenBank accession No.: ITS=MK207059, TEF1 $\alpha=$ MK190727, RPB2 = MK190729.

Other material examined Paratypes: Southwest Indian Ocean, from deep-sea sediment (longitude 63.92E, latitude 27.77S, depth $3166 \mathrm{~m}$ ), 2014, collected by the Chinese research vessel Dayang Yihao (Ocean No. 1), 30I-SWIR-S003TVG01, living culture LC12846. GenBank accession No.: ITS=MK207060, TEF1- $\alpha=$ MK190728, RPB2 $=$ MK190730.

\section{World distribution Southwest Indian Ocean.}

Habitat Deep sea sediment.

Notes: Fusarium spp. occur as endophytes, pathogens and saprophytes in marine habitats (Khao et al. 2005, Damare et al. 2006, Jones et al. 2009, 2015, SarmientoRamirez et al. 2010). Herein we introduced a novel species, Fusarium sedimenticola isolated from deep-sea sediment collected from the Southwest Indian Ocean. Phylogenetic analyses of a multi-locus dataset (ITS, TEF 1- $\alpha$ and RPB2) were performed using Bayesian inference (BI) and maximum likelihood (ML) methods. The new species is phylogenetically nested in the Fusarium solani 

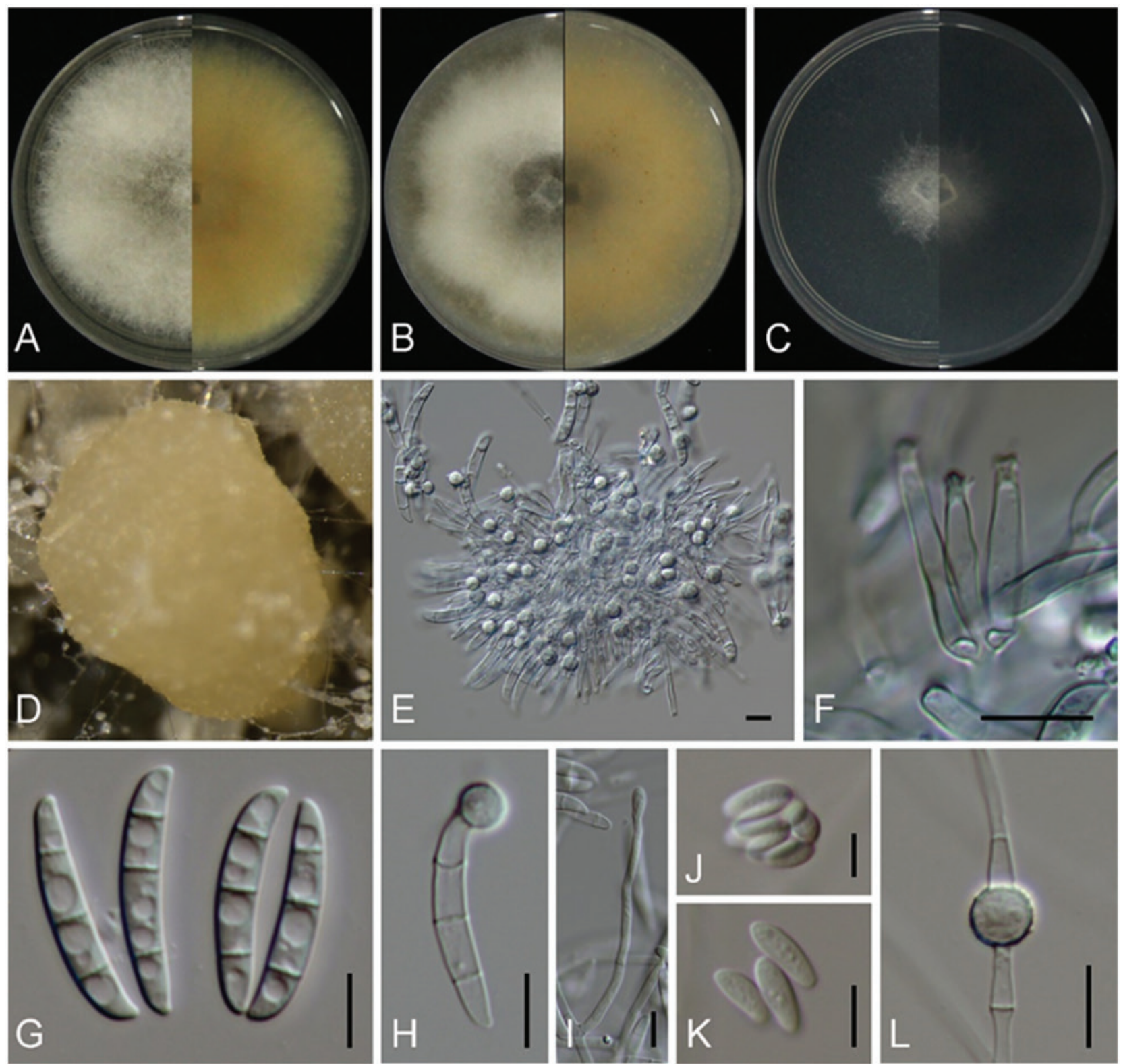

Figure 12: Fusarium sedimenticola (ex-type strain LC12845).

(A-C) Surface (left) and back (right) of colonies on potato dextrose agar, oat agar, and synthetic nutrient poor agar, respectively, after $7 \mathrm{~d}$ at $25^{\circ} \mathrm{C}$ in the dark. (D) Sporodochium formed on the surface of carnation leaves. (E-F) Sporodochial conidiophores. (G-H) Sporodochial macroconidia. (I) Monophialide on aerial hyphae. (J-K) Microconidia. (L) Chlamydospore. Scale bars $=10 \mu \mathrm{m}$.

(Mart.) Sacc. species complex (FSSC) and closely related to Fusarium keratoplasticum Geiser, O’Donnell, D.P.G. Short et Ning Zhang (1 bp difference in ITS, $10 \mathrm{bp}$ in TEF1$\alpha$ and 6 bp in RPB2). Morphologically, the two relatives differ from each other in producing different numbers of septa to the macroconidia (3-septate in F. sedimenticola vs. 3-4-septate in F. keratoplasticum). In addition, $F$. sedimenticola could be easily distinguished from all other known FSSC species in forming a globose cell at the apex of the macroconidia.

\section{Discussion}

This paper is a collection of new species of marine fungi occurring on different substrates (driftwood, mangrove wood Aegiceras cornicualtum, Avicvennia marina, brackish water palm Phoenix paludosa and deep water sediments) sampled in different parts of the world (India, Sweden, UK, South Indian Ocean) collected by various mycologists. The current number of accepted marine fungi stands at 1257 species and the taxa introduced in 


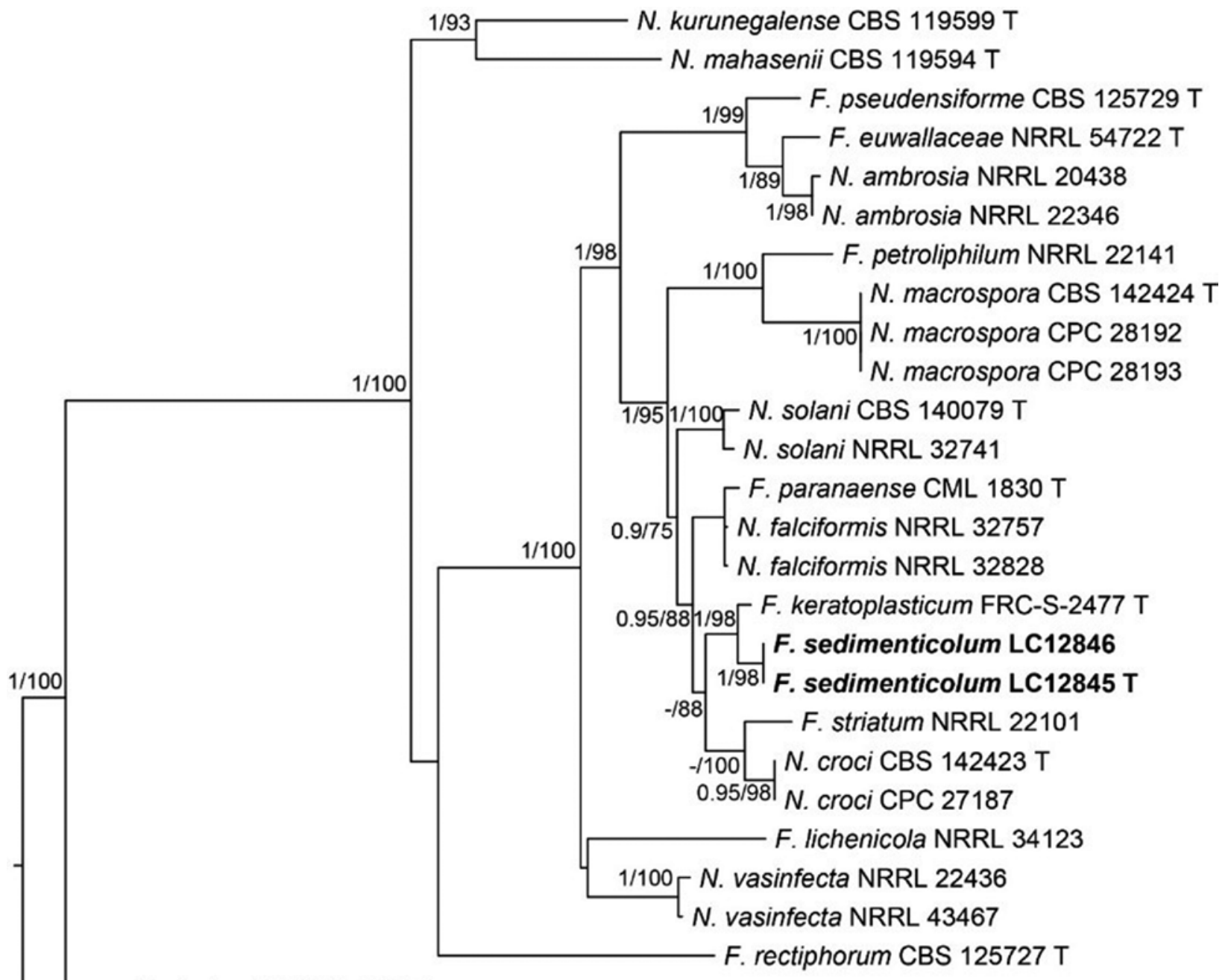

F. plagianthi NRRL 22632

N. illuden NRRL 22090

0.02

Figure 13: Fifty percent majority rule consensus tree from a Bayesian analysis based on a three-locus combined dataset (ITS, TEF1- $\alpha$ and RPB2) showing phylogenetic relationships of species within the Fusarium solani (Mart.) Sacc. species complex.

Bayesian posterior probabilities (PP $>0.9$ ) and maximum likelihood $(M L)$ bootstrap support values $(B S>70)$ are displayed at the nodes (PP/ML). The tree was rooted to Neocosmospora illuden (Berk.) L. Lombard et Crous (NRRL 22090). Novel species is marked in bold. Ex-type cultures are indicated with $\mathrm{T} ; N_{.}=$Neocosmospora, $F_{.}=$Fusarium.

this paper expand our knowledge of the diversity of this ecological group of fungi. In the previous Botanic Marina Special Issue (Abdel-Wahab et al. 2017), the number of marine fungi was 1112, thus 145 marine species have been introduced by sampling a wider range of substrates, e.g. deep water sediments, and worldwide locations (Jones 2011).

Acknowledgments: E.B. Gareth Jones is supported under the Distinguished Scientist Fellowship Program (DSFP), King Saud University, Kingdom of Saudi Arabia. V. Venkateswara
Sarma would like to thank Ministry of Earth Sciences (MOES), Govt. of India (Sanction order: MOES/36/OO1S/ Extra/40/2014/PC-IV dt.14.1.2015) for funding the project and Department of Biotechnology, Pondicherry University for providing the facilities. The Tamil Nadu forest department and DFO, Tiruvarur district, Tamil Nadu are thanked for providing permission to collect specimens from Muthupet mangroves. B. Devadatha would like to thank the Pondicherry University and MOES, Govt. of India for providing fellowships. Fang Liu thanks the program of China Ocean Mineral Resources R\&D Association (No. DY125-22-QY-33) for 
financial support. The Swedish Species Initiative ("ArtDatabanken") is thanked for support within the project "Marine fungi in Sweden" (SLU.dha.2017.4.3-73). Kevin D. Hyde would like to thank the Thailand grants (no. RSA5980068, no. RDG6130001 and no. 60201000201) for supporting research. Jian-Kui Liu thanks the National Natural Science Foundation of China (NSFC 31600032) and Science and Technology Foundation of Guizhou Province (LH [2015]7061).

\section{References}

Abdel-Wahab, M.A., D.C. Dayarathne, S. Suetrong, S.Y. Guo, S.A. Alias, A.H. Bahkali, T. Nagahama, A.M. Elgorban, F.A. AbdelAziz, M.S. Hodhod, M.O. Al-Hebshi, K.D. Hyde, N.A.B.M. Nor, K.L. Pang and E.B.G. Jones. 2017. New saprobic marine fungi and a new combination. Bot. Mar. 60: 469-488.

Amend, A., G. Burgaud, M. Cunliffe, V.P. Edgcomb, C.L. Ettingerc, M.H. Gutiérrez, J. Heitman, E.F.Y. Hom, G. Ianiri, A.C. Jones, K. Kagami, K.P. Picard, C.A. Quandt, S. Raghukumar, M. Riquelme, J. Stajich, J. Vargas-Muñiz, A.K. Walker, O. Yarden and A.S. Gladfelter. 2019. Fungi in the marine environment: open questions and unsolved problems. mBio 10: R189-R204.

Ariyawansa, H.A., K.D. Hyde, S.C. Jayasiri, B. Buyck, K.W.T. Chethana, D.Q. Dai, Y.C. Dai, D.A. Daranagama, R.S. Jayawardena, R. Lücking, M. Ghobad-Nejhad, T. Niskanen, K.M. Thambugala, K. Voigt, R.L. Zhao, G.J. Li, M. Doilom, S. Boonmee, Z.L. Yang, Q. Cai, Y.Y. Cui, A.H. Bahkali, J. Chen, B.K. Cui, J.J. Chen, M.C. Dayarathne, A.J. Dissanayake, A.H. Ekanayaka, A. Hashimoto, S. Hongsanan, E.B.G. Jones, E. Larsson, W.J. Li, Q.R. Li, J.K. Liu, Z.L. Luo, S.S.N. Maharachchikumbura, A. Mapook, E.H.C. McKenzie, C. Norphanphoun, S. Konta, K.L. Pang, R.H. Perera, R. Phookamsak, C. Phukhamsakda, U. Pinruan, E. Randrianjohany, C. Singtripop, K. Tanaka, C.M. Tian, S. Tibpromma, M.A. Abdel-Wahab, D.N. Wanasinghe, N.N. Wijayawardene, J.F. Zhang, H. Zhang, F.A. Abdel-Aziz, M. Wedin, M. Westberg, J.F. Ammirati, T.S. Bulgakov, D.X. Lima, T.M. Callaghan, P. Callac, C.H. Chang, L.F. Coca, M. DalForno, V. Dollhofer, K. Fliegerová, K. Greiner, G.W. Griffith, H.M. Ho, V. Hofstetter, R. Jeewon, J.C. Kang, T.C. Wen, P.M. Kirk, I. Kytövuori, J.D. Lawrey, J. Xing, H. Li, Z.Y. Liu, X.Z. Liu, K. Liimatainen, H. Thorsten Lumbsch, M. Matsumura, B. Moncada, S. Nuankaew, S. Parnmen, A.L.C.M. de Azevedo Santiago, S. Sommai, Y. Song, C.A.F. de Souza, C.M. de Souza-Motta, H.Y. Su, S. Suetrong, Y. Wang, W.S. Fong, H.S. Yuan, L.W. Zhou, M. Réblová, J. Fournier, E. Camporesi, J.J. Luangsa-ard, K. Tasanathai, A. Khonsanit, D. Thanakitpipattana, S. Somrithipol, P. Diederich, A.M. Millanes, R.S. Common, M. Stadler, J.Y. Yan, X.H. Li, H.W. Lee, T.T.T. Nguyen, H.B. Lee, E. Battistin, O. Marsico, A. Vizzini, J. Vila, E. Ercole, U. Eberhardt, G. Simonini, H.A. Wen and X.H. Chen. 2015. Fungal diversity notes 111-252 - taxonomic and phylogenetic contributions to fungal taxa. Fungal Divers. 75: 27-274.

Asgari, B., R. Zare and W. Gams. 2007. Coniochaeta ershadii, a new species from Iran, and a key to well-documented Coniochaeta species. Nova Hedw. 84: 175-187.

Bonorden, H.F. 1851. Handbuch der allgemeinen Mykologie. Schweizerbart'sche Verlagshandlung, Stuttgart. pp. 1-336.
Cain, R.F. 1961. Studies of soil fungi: iii. new species of Coniochaeta, Chaetomidium, and Thielavia. Can. J. Bot. 39: 1231-1239.

Checa J., J.M. Barrasa, G. Moreno, F. Fort and J. Guarro. 1988. The genus Coniochaeta (Sacc.) Cooke (Coniochaetaceae, Ascomycotina) in Spain. Cryptog. Mycol. 9: 1-34.

Crous, P.W., M.J. Wingfield, T.I. Burgess, G.E. Hardy, C. Crane, S. Barrett, J.F. Cano-Lira, J.J. Le Roux, R. Thangavel, J. Guarro, A.M. Stchigel, M.P. Martín, D.S. Alfredo, P.A. Barber, R.W. Barreto, I.G. Baseia, J. Cano-Canals, R. Cheewangkoon, R.J. Ferreira, J. Gené, C. Lechat, G. Moreno, F. Roets, R.G. Shivas, J.O. Sousa, Y.P. Tan, N.P. Wiederhold, S.E. Abell, T. Accioly, J.L. Albizu, J.L. Alves, Z.I. Antoniolli, N. Aplin, J. Araújo, M. Arzanlou, J.D.P. Bezerra, J.P. Bouchara, J.R. Carlavilla, A. Castillo, V.L. Castroagudín, P.C. Ceresini, G.F. Claridge, G. CoeIho, V.R.M. Coimbra, L.A. Costa, K.C. da Cunha, S.S. da Silva, R. Daniel, Z.W. de Beer, M. Dueñas, J. Edwards, P. Enwistle, P.O. Fiuza, J. Fournier, D. García, T.B. Gibertoni, S. Giraud, M. Guevara-Suárez, L.F.P. Gusmão, S. Haituk, M. Heykoop, Y. Hirooka, T.A. Hofmann, J. Houbraken, D.P. Hughes, I. Kautmano vá, O. Koppel, O. Koukol, E. Larsson, K.P.D. Latha, D.H. Lee, D.O. Lisboa, W.S. Lisboa, Á. López-Villalba, J.L.N. Maciel, N.P. Manimohan, J.L. Manjón, S. Marincowitz, T.S. Marney, M. Meijer, A.N. Miller, I. Olariaga, L.M. Paiva, M. Piepenbring, J.C. Poveda-Molero, K.N.A. Raj, H.A. Raja, A. Rougeron, I. Salcedo, R. Samadi, T.A.B. Santos, K. Scarlett, K.A. Seifert, L.A. Shuttleworth, G.A. Silva, M. Silva, J.P.Z. Siqueira, C.M. Souza-Motta, S.L. Stephenson, D.A. Sutton, N. Tamakeaw, M.T. Telleria, N. Valenzuela-Lopez, A.Viljoen, C.M. Visagie, A. Vizzini, F. Wartchow, B.D. Wingfield, E. Yurchenko, J.C. Zamora and J.Z. Groenewald. 2016. Fungal Planet description sheets: 469-557. Persoonia 37: 218-403.

Damare, S., C. Raghukumar and S. Raghukumar. 2006. Fungi in deep-sea sediments of the Central Indian Basin. Deep-Sea Res. I53:14-27.

Damm, U., P.H. Fourie and P.W. Crous. 2010. Coniochaeta (Lecythophora), Collophora gen. nov. and Phaeomoniella species associated with wood necroses of Prunus trees. Persoonia 24: $60-80$.

Devadatha, B., V.V. Sarma, H.A. Ariyawansa and E.B.G. Jones. 2018. Deniquelata vittalii sp. nov., a novel Indian saprobic marine fungus on Suaeda monoica and two new records of marine fungi from Muthupet mangroves, East coast of India. Mycosphere 9: 565-582.

Eriksson, O.E., H.O. Baral, R.S. Currah, K. Hansen, C.P. Kurtzman, G. Rambold and T. Laessøe. 2004. Outline of the Ascomycetes - 2004. Myconet 10: 1-99.

García, D., A.M. Stchigel, J. Cano, M. Calduch, D.L. Hawksworth and J. Guarro. 2006. Molecular phylogeny of Coniochaetales. Mycol. Res. 110: 1271-1289.

Garzoli, L., A. Poli, V. Prigione, G. Gnavi and G.C. Varese. 2018. Peacock's tail with a fungal cocktail: first assessment of the mycobiota associated with the brown alga Padina pavonica. Fungal Ecol. 35: 87-97.

Gerlach, W. and H. Nirenberg. 1982. The genus Fusarium - a pictorial atlas. Mitteilungen aus der Biologischen Bundesanstalt fur Land- und Forstwirtschaft Berlin-Dahlem 209: 1-406.

Gladfelter, A.S., T.Y. James and A.S. Amend. 2019. Marine fungi. Curr. Biol. 29: R191-R195. 
Gräfenhan, T., H.J. Schroers, H.I. Nirenberg and K.A. Seifert. 2011. An overview of the taxonomy, phylogeny, and typification of nectriaceous fungi in Cosmospora, Acremonium, Fusarium, Stilbella, and Volutella. Stud. Mycol. 68: 79-113.

Hongsanan, S., S.S.N. Maharachchikumbura, K.D. Hyde, M.C. Samarakoon, R. Jeewon, Q. Zhao, A.M. Al-Sadi and A.H. Bahkali. 2017. An updated phylogeny of Sordariomycetes based on phylogenetic and molecular clock evidence. Fungal Divers. 84: 25-41.

Huang, S.K., R. Jeewon, K.D. Hyde, D.J. Bhat and T.C. Wen. 2018. Novel taxa within Nectriaceae: Cosmosporella gen. nov. and Aquanectria sp. nov. from freshwater habitats in China. Crypto. Mycol. 39: 169-192.

Huhndorf, S.M., A.N. Miller and F.A. Fernández. 2004. Molecular systematics of the Sordariales: the order and the family Lasiosphaeriaceae redefined. Mycologia 96: 368-387.

Hyde, K.D. 1991. Helicascus kanaloanus, Helicascus nypae sp. nov. and Salsuginea ramicola gen. et sp. nov. from intertidal mangrove wood. Bot. Mar. 34: 311-318.

Hyde, K.D. 1992. Intertidal mangrove fungi from the west coast of Mexico, including one new genus and two new species. Mycol. Res. 96: 25-30.

Hyde, K.D. and E.B.G. Jones. 1988. Marine mangrove fungi. P.S.Z.N.I.: Mar. Ecol. 9: 15-33.

Hyde, K.D., E.B.G. Jones, J.K. Liu, H.A. Ariyawansa, E. Boehm, S. Boonmee, U. Braun, P. Chomnunti, P.W. Crous, D.Q. Dai, P. Diederich, A.J. Dissanayake, M. Doilom, F. Doveri, S. Hongsanan, R. Jayawardena, J.D. Lawrey, Y.M. Li, Y.X. Liu, R. Lücking, J. Monkai, L. Muggia, M.P. Nelsen, K.L. Pang, R. Phookamsak, I. Senanayake, C.A. Shearer, S. Seutrong, K. Tanaka, K.M. Thambugala, D.N.N. Wijayawardene, S. Wikee, H.X. Wu, Y. Zhang, B. Aguirre-Hudson, S.A. Alias, A. Aptroot, A.H. Bahkali, J.L. Bezerra, J.D. Bhat, E. Camporesi, E. Chukeatirote, C. Gueidan, D.L. Hawksworth, K. Hirayama, S. De Hoog, J.C. Kang, K. Knudsen, W.J. Li, X.H. Li, Z.Y. Liu, A. Mapook, E.H.C. McKenzie, A.N. Miller, P.E. Mortimer, A.J.L. Phillips, H.A. Raja, C. Scheuer, F. Schumm, J.E. Taylor, Q. Tian, S. Tibpromma, D.N. Wanasinghe, Y. Wang, J.C. Xu, J.Y. Yan, S. Yacharoen and M. Zhang. 2013. Families of Dothideomycetes. Fungal Divers. 63: 1-313.

Hyde, K.D., C. Norphanphoun, V.P. Abreu, A. Bazzicalupo, K.W. Thilini Chethana, M. Clericuzio, M.C. Dayarathne, A.J. Dissanayake, A.H. Ekanayaka, M.Q. He, S. Hongsanan, S.K. Huang, S.C. Jayasiri, R.S. Jayawardena, A. Karunarathna, S. Konta, L. Kušan, H. Lee, J.F. Li, C.G. Lin, N.G. Liu, Y.Z. Lu, Z.L. Luo, I.S. Manawasinghe, A. Mapook, R.H. Perera, R. Phookamsak, C. Phukhamsakda, L. Siedlecki, A.M. Soares, D.S. Tennakoon, Q. Tian, S. Tibpromma, D.N. Wanasinghe, Y.P. Xiao, J. Yang, X.Y. Zeng, F.A. Abdel-Aziz, W.J. Li, I.C. Senanyake, Q.J. Shang, D.A. Daranagama, N.I. de Silva, K.M. Thambugala, M.A. AbdelWahab, A.H. Bahkali, M.L. Berbee, S. Boonmee, D.J. Bhat, T.S. Bulgakov, B. Buyck, E. Camporesi, R.F. Castañeda-Ruiz, P. Chomnunti, M. Doilom, F. Dovana, T.B. Gibertoni, M, Jadan, R. Jeewon, E.B.G. Jones, J.C. Kang, S.C. Karunarathna, Y.W. Lim, J.K. Liu, Z.Y. Liu, H.L. Plautz Jr., S. Lumyong, S.S.N. Maharachchikumbura, N. Matočec, E.H.C. McKenzie, A. Mešić, D. Miller, J. Pawłowska, Q.L. Pereira, I. Promputtha, A.I. Romero, L. Ryvarden, H.Y. Su, S. Suetrong, Z. Tkalčec, A. Vizzini, T.C. Wen, K. Wisitrassameewong, M. Wrzosek, J.C. Xu, Q. Zhao, R.L. Zhao and P.E. Mortimer. 2017. Fungal diversity notes 603-708: taxonomic and phylogenetic notes on genera and species. Fungal Divers. 87: 1-235.
Hyde, K.D., N. Chaiwan, C. Norphanphoun, S. Boonmee, E. Camporesi, K.W.T. Chethana, M.C. Dayarathne, N.I. de Silva, A.J. Dissanayake, A.H. Ekanayaka, S. Hongsanan, S.K. Huang, S.C. Jayasiri, R.S. Jayawardena, H.B. Jiang, A. Karunarathna, C.G. Lin, J.K. Liu, N.G. Liu, Y.Z. Lu, Z.L. Luo, S.S.N. Maharachchimbura, I.S. Manawasinghe, D. Pem, R.H. Perera, C. Phukhamsakda, M.C. Samarakoon, C. Senwanna, Q.J. Shang, D.S. Tennakoon, K.M. Thambugala, S. Tibpromma, D.N. Wanasinghe, Y.P. Xiao, J. Yang, X.Y. Zeng, J.F. Zhang, S.N. Zhang, T.S. Bulgakov, D.J. Bhat, R. Cheewangkoon, T.K. Goh, E.B.G. Jones, J.C. Kang, R. Jeewon, Z.Y. Liu, S. Lumyong, C.H. Kuo, E.H.C. McKenzie, T.C. Wen, J.Y. Yan and Q. Zhao. 2018. Mycosphere notes 169-224. Mycosphere 9: 271-430.

Jones, E.B.G. 2011. Are there more marine fungi to be described? Bot. Mar. 54: 343-354.

Jones, E.B.G. and K.D. Hyde. 1988. Methods for the study of mangrove marine fungi from the mangroves. In: (A.D. Agate, C.V. Subramanian and M. Vannucci, eds) Mangrove microbiology. Role of microorganisms in nutrient cycling of mangrove soils and waters. UNDP. UNESCO, New Delhi. pp. 9-27.

Jones, E.B.G. and K.L. Pang. 2012. Introduction. In: (E.B.G. Jones and K.L. Pang, eds) Marine fungi and fungal-like organisms. De Gruyter, Germany. pp. 1-13.

Jones, E.B.G. and K.L. Pang. 2017. Recent advances in marine mycology. Bot. Mar. 60: 361-367.

Jones, E.B.G., J. Sakayaroj, S. Suetrong, S. Somrithipol and K.L. Pang. 2009. Classification of marine Ascomycota, anamorphic taxa and Basidiomycota. Fungal Divers. 35: 1-187.

Jones, E.B.G., S. Suetrong, J. Sakayaroj, A.H. Bahkali, M.A. AbdelWahab, T. Boekhout and K.L. Pang. 2015. Classification of marine Ascomycota, Basidiomycota, Blastocladiomycota and Chytridiomycota. Fungal Divers. 73: 1-72.

Jones, E.B.G., K.L. Pang, M.A. Abdel-Wahab, B. Scholz, K.D. Hyde, T. Boekhout, R. Ebel, M.E. Rateb, L. Henderson, J. Sakayaroj, S. Suetrong, M.C. Dayarathne, V. Kumar, S. Raghukumar, K.R. Sridhar, A.H. Bahkali1, F. Gleason and C. Norphanphoun. 2019. An online resource for marine fungi. Fungal Divers. 96: 347-433.

Khan, Z., J. Gené, S. Ahmad, J. Cano, N. Al-Sweih, L. Joseph, R. Chandy and J. Guarro. 2013. Coniochaeta polymorpha, a new species from endotracheal aspirate of a preterm neonate, and transfer of Lecythophora species to Coniochaeta. Anton. van Leeuw. 104: 243-252.

Khao L.V., K. Hatai, A. Yuasa and K. Sawada. 2005. Morphology and molecular phylogeny of Fusarium solani isolated from kuuruma prawn Penaeus japonicas with black gills. Fish Pathol. 40: 103-109.

Kirk, P.M., P.F. Cannon, J.C. David and J.A. Stalpers. 2001. Ainsworth \& Bisby's dictionary of the fungi. 9th edition. CABI Publishing, Wallingford. pp. 655.

Kirk, P.M., P.F. Cannon, D.W. Minter and J.A. Stalpers. 2008. Dictionary of the fungi. 10th edition. CABI, Wallingford. pp. 771.

Kohlmeyer, J. and B. Volkmann-Kohlmeyer. 1991. Illustrated key to the filamentous higher marine fungi. Bot. Mar. 34: 1-61.

Lechat, C. and A. Rossman. 2017. A new species of Fusicolla (Hypocreales), F. ossicola, from Belgium. Ascomycete.org 9: 225-228.

Li, G.J., K.D. Hyde, R.L. Zhao, S. Hongsanan, F.A. Abdel-Aziz, M.A. Abdel-Wahab, P. Alvarado, G. Alves-Silva, S.F. Ammirati, H.A. Ariyawansa, A. Baghela, A.H. Bahkali, M. Beug, D.J. Bhat, D. Bojantchev, T. Boonpratuang, T.S. Bulgakov, E. Camporesi, M.C. 
Boro, O. Ceska, D. Chakraborty, J.J. Chen, K.W.T. Chethana, P. Chomnunti, G. Consiglio, B.K. Cui, D.Q. Dai, Y.C. Dai, D.A. Daranagama, K. Das, M.C. Dayarathne, E. De Crop, R.J.V. De Oliveira, C.A.F. de Souza, J.I. de Souza, B.T.M. Dentinger, A.J. Dissanayake, M. Doilom, E.R. Drechsler-Santos, M. Ghobad-Nejhad, S.P. Gilmore, A. Góes-Neto, M. Gorczak, C.H. Haitjema, K.K. Hapuarachchi, A. Hashimoto, M.Q. He, J.K. Henske, K. Hirayama, M.J. Iribarren, S.C. Jayasiri, R.S. Jayawardena, S.J. Jeon, G.H. Jerônimo, A.L. Jesus, E.B.G. Jones, J.C. Kang, S.C. Karunarathna, P.M. Kirk, S. Konta, E. Kuhnert, E. Langer, H.S. Lee, H.B. Lee, W.J. Li, X.H. Li, K. Liimatainen, D.X. Lima, C.G. Lin, J.K. Liu, X.Z. Liu, Z.Y. Liu, J.J. Luangsa-ard, R. Lücking, H.T. Lumbsch, S. Lumyong, E.M. Leaño, A.V. Marano, M. Matsumura, E.H.C. McKenzie, S. Mongkolsamrit, P.E. Mortimer, T.T.T. Nguyen, T. Niskanen, C. Norphanphoun, M.A. O'Malley, S. Parnmen, J. Pawłowska, R.H. Perera, R. Phookamsak, C. Phukhamsakda, C.L.A. Pires-Zottarelli, O. Raspé, M.A. Reck, S.C.O. Rocha, A.L.C.M.A. de Santiago, I.C. Senanayake, L. Setti, Q.J. Shang, S.K. Singh, E.B. Sir, K.V. Solomon, J. Song, P. Srikitikulchai, M. Stadler, S. Suetrong, H. Takahashi, T. Takahashi, K. Tanaka, L.P. Tang, K.M. Thambugala, D. Thanakitpipattana, M.K. Theodorou, B. Thongbai, T. Thummarukcharoen, Q. Tian, S. Tibpromma, A. Verbeken, A. Vizzini, J. Vlasák, K. Voigt, D.N. Wanasinghe, Y. Wang, G. Weerakoon, H.A. Wen, T.C. Wen, N.N. Wijayawardene, S. Wongkanoun, M. Wrzosek, Y.P. Xiao, J.C. Xu, J.Y. Yan, J. Yang, S.D. Yang, Y. Hu, J.F. Zhang, J. Zhao, L.W. Zhou, D. Peršoh, A.J.L. Phillips and S.S.N. Maharachchikumbura. 2016. Fungal diversity notes 253-366: taxonomic and phylogenetic contributions to fungal taxa. Fungal Divers. 78: 1-237.

Liu, Y.J., S. Whelen and B.D. Hall. 1999. Phylogenetic relationships among ascomycetes: evidence from an RNA polymerse II subunit. Mol. Biol. Evol. 16: 1799-1808.

Liu, J.K., K.D. Hyde, R. Jeewon, A.J.L. Phillips, S.S.N. Maharachchikumbura, M. Ryberg, Z.Y. Liu and Q. Zhao. 2017. Ranking higher taxa using divergence times: a case study in Dothideomycetes. Fungal Divers. 84: 75-99.

Maharachchikumbura, S.S.N., K.D. Hyde, E.B.G. Jones, E.H.C. McKenzie, S.K. Huang, M.A. Abdel-Wahab, D.A. Daranagama, M. Dayarathne, M.J. D’Souza, I.D. Goonasekara, S. Hongsanan, R.S. Jayawardena, P.M. Kirk, S. Konta, J.K. Liu, Z.Y. Liu, C. Norphanphoun, K.L. Pang, R.H. Perera, I.C. Senanayake, Q. Shang, B.D. Shenoy, Y.P. Xiao, A.H. Bahkali, J.C. Kang, S. Somrothipol, S. Suetrong, T.C. Wen and J.C. Xu. 2015. Towards a natural classification and backbone tree for Sordariomycetes. Fungal Divers. 72: 199-301.

Maharachchikumbura, S.S.N., K.D. Hyde, E.B.G. Jones, E.H.C. McKenzie, J.D. Bhat, M.C. Dayarathne, S.K. Huang, C. Norphanphoun, I.C. Senanayake, R.H. Perera, Q.J. Shang, Y. Xiao, M.J. D'souza, S. Hongsanan, R.S. Jayawardena, D.A. Daranagama, S. Konta, I.D. Goonasekara, W.Y. Zhuang, R. Jeewon, A.J.L. Phillips, M.A. Abdel-Wahab, A.M. Al-Sadi, A.H. Bahkali, S. Boonmee, N. Boonyuen, R. Cheewangkoon, A.J. Dissanayake, J. Kang, Q.R. Li, J.K. Liu, X.Z. Liu, Z.Y. Liu, J.J. Luangsa-ard, K.L. Pang, R. Phookamsak, I. Promputtha, S. Suetrong, M. Stadler, T.C. Wen and N.N. Wijayawardene. 2016. Families of Sordariomycetes. Fungal Divers. 79: 1-317.

Miller, A.N., S.M. Huhndorf and J. Fournier. 2014. Phylogenetic relationships of five uncommon species of Lasiosphaeria and three new species in the Helminthosphaeriaceae (Sordariomycetes). Mycologia 106: 505-524.
Pang, K.L., J.S. Jheng and E.B.G. Jones. 2011. Marine mangrove fungi of Taiwan. National Taiwan Ocean University, Chilung. pp. 1-131.

Perdomo, H., D. García, J. Gené, J. Cano, D.A. Sutton, R. Summerbell and J. Guarro. 2013. Phialemoniopsis, a new genus of Sordariomycetes, and new species of Phialemonium and Lecythophora. Mycologia 105: 398-421.

Raghukumar, S. 2017. The marine environment and the role of fungi. In: (S. Raghukumar, ed) Fungi in coastal and oceanic marine ecosystems. Springer, Cham. pp. 17-38.

Rehner, S.A. and E. Buckley. 2005. A Beauveria phylogeny inferred from nuclear ITS and EF1- $\alpha$ sequences: evidence for cryptic diversification and links to Cordyceps teleomorphs. Mycologia 97: 84-98.

Saccardo, P.A. 1878. Fungi Italici autographice delineati a Prof. P.A. Saccardo. Patavii 1878. - Fascicoli V.-VIII. Michelia 1: 326-350.

Samarakoon, M.C., Y. Gafforov, N. Liu, S.S. Maharachchikumbura, J.D. Bhat, J.K. Liu, I. Promputtha and K.D. Hyde. 2018. Combined multi-gene backbone tree for the genus Coniochaeta with two new species from Uzbekistan. Phytotaxa 336: 43-58.

Sarmiento-Ramírez, J.M., E. Abella, M.P. Martín, M.T. Tellería, L.F. López-Jurado, A. Marco and J. Diéguez-Uribeondo. 2010.

Fusarium solani is responsible for mass mortalities in nests of loggerhead sea turtle, Caretta caretta, in Boavista, Cape Verde. FEMS Microbiol. Lett. 312: 192-200.

Suetrong, S., C.L. Schoch, J.W. Spatafora, J. Kohlmeyer, B. Volkmann-Kohlmeyer, J. Sakayaroj, S. Phongpaichit, K. Tanaka, K. Hirayama and E.B.G. Jones. 2009. Molecular systematics of the marine Dothideomycetes. Stud. Mycol. 64: 155-173.

Suetrong, S., K.D. Hyde, Y. Zhang, A.H. Bahkali and E.B.G. Jones. 2011. Trematosphaeriaceae fam. nov. (Dothideomycetes, Ascomycota). Cryptog. Mycol. 32: 343-358.

Swofford, D.L. 2002. PAUP*. Phylogenetic analysis using parsimony ( ${ }^{*}$ and other methods). Version 4. Sinauer Associates, Sunderland, Massachusetts, USA.

Trouillas, F.P., WM. Pitt, M.R. Sosnowski, R. Huang, F. Peduto, A. Loschiavo, S. Savocchia and F.S. Scott. 2011. Taxonomy and DNA phylogeny of Diatrypaceae associated with Vitis vinifera and other woody plants in Australia. Fungal Divers. 49: 203-223.

Troy, G.C., D.L. Panciera, J.P. Pickett, D.A. Sutton, J. Gene, J.F. Cano, J. Guarro, E.H. Thompson and B.L. Wickes. 2013. Mixed infection caused by Lecythophora canina sp. nov. and Plectosphaerella cucumerina in a German shepherd dog. Med. Mycol. 51: 455-460.

Tubaki, K., C. Booth and T. Harada. 1976. A new variety of Fusarium merismoides. Trans. Br. Mycol. Soc. 66: 355-356.

Vázquez-Campos, X., A.S. Kinsela, T.D. Waite, R.N. Collins and B.A. Neilan. 2014. Fodinomyces uranophilus gen. nov. sp. nov. and Coniochaeta fodinicola sp. nov., two uranium mine-inhabiting Ascomycota fungi from northern Australia. Mycologia 106: 1073-1089.

Vilgalys, R. and M. Hester. 1990. Rapid genetic identification and mapping of enzymatically amplified ribosomal DNA from several Cryptococcus species. J. Bacteriol. 172: 4238-4246.

Wanasinghe, D.N., R. Jeewon, S. Tibpromma, E.B.G. Jones and K.D. Hyde. 2017. Saprobic Dothideomycetes in Thailand: Muritestudina gen. et sp. nov. (Testudinaceae) a new terrestrial pleosporalean ascomycete, with hyaline and muriform ascospores. Stud. Fungi 2: 219-234. 
Wanasinghe, D.N., C. Phukhamsakda, K.D. Hyde, R. Jeewon, H.B. Lee, E.B.G. Jones, S. Tibpromma, D.S. Tennakoon, A.J. Dissanayake, S.C. Jayasiri, Y. Gafforov, E. Camporesi, T.S. Bulgakov, A.H. Ekanayake, R.H. Perera, M.C. Samarakoon, I.D. Goonasekara, A. Mapook, W.J. Li, I.C. Senanayake, J.F. Li, C. Norphanphoun, M. Doilom, A.H. Bahkali, J.C. Xu, P.E. Mortimer, L. Tibell, S. Tibell and S.C. Karunarathna. 2018. Fungal diversity notes 709-839: taxonomic and phylogenetic contributions to fungal taxa with an emphasis on fungi on Rosaceae. Fungal Divers. 89: 1-236.

Weber, E. 2002. The Lecythophora-Coniochaeta complex I. Morphological studies on Lecythophora species isolated from Picea abies. Nova Hedw. 74: 159-185.

Weber, E., C. Görke and D. Begerow. 2002. The Lecythophora-Coniochaeta complex: II. Molecular studies based on sequences of the large subunit of ribosomal DNA. Nova Hedw. 74: 187-200.

White, T.J., T. Bruns, S. Lee and J. Taylor. 1990. Amplification and direct sequencing of fungal ribosomal RNA genes for phylogenetics. In: (M.A. Innis, D.H. Gelfand, J.J. Sninsky and T.J. White, eds) PCR protocols: a guide tomethods and applications. Academic Press, New York. pp. 315-322.

Wijayawardene, N.N., K.D. Hyde, K.C. Rajeshkumar, D.L. Hawksworth, H. Madrid, P.M. Kirk, U. Braun, R.V. Singh, P.W. Crous, M. Kukwa, R. Lücking, C.P. Kurtzman, A. Yurkov, D. Haelewaters, A. Aptroot, H.T. Lumbsch, E. Timdal, D. Ertz, J. Etayo, A.J.L. Phillips, J.Z. Groenewald, M. Papizadeh, L. Selbmann, M.C. Dayarathne, G. Weerakoon, E.B.G. Jones, S. Suetrong, Q. Tian, R.F. Castanéda-Ruiz, A.H. Bahkali, K.L. Pang, K. Tanaka, D.Q. Dai, J. Sakayaroj, M. Hujslová, L. Lombard, B.D. Shenoy, A. Suija, S.S.N. Maharachchikumbura, K.M. Thambugala, D.N. Wanasinghe, B.O. Sharma, S. Gaikwad, G. Pandit, L. Zucconi, S. Onofri, E. Egidi, H.A. Raja, R. Kodsueb, M.E.S. Cáceres, S. Pérez-Ortega, P.O. Fiuza, J.S. Monteiro, L.N. Vasilyeva, R.G. Shivas, M. Prieto, M. Wedin, I. Olariaga, A.A. Lateef, Y. Agrawal, S.A.S. Fazeli, M.A. Amoozegar, G.Z. Zhao, W.P. Pfliegler, G. Sharma, M. Oset, M.A. Abdel-Wahab, S. Takamatsu, K. Bensch, N.I. de Silva, A. De Kesel, A. Karunarathna, S. Boonmee, D.H. Pfister, Y.Z. Lu, Z.L. Luo, N. Boonyuen, D.A. Daranagama, I.C. Senanayake, S.C. Jayasiri, M.C. Samarakoon, X.Y. Zeng, M. Doilom, L. Quijada, S. Rampadarath, G. Heredia, A.J. Dissanayake, R.S. Jayawardana, P.H. Perera, L.Z. Tang, C. Phukhamsakda, M. Hernández-Restrepo, X.Y. Ma, S. Tibpromma, L.F.P. Gusmao, D. Weerahewa and S.C. Karunarathna. 2017. Notes for genera: Ascomycota. Fungal Divers. 86: 1-594.

Wijayawardene, N.N., K.D. Hyde, H.T. Lumbsch, J.K. Liu, S.S.N. Maharachchikumbura, A.H. Ekanayaka, Q. Tian and R. Phookamsak. 2018. Outline of Ascomycota: 2017. Fungal Divers. 88: 167-263.

Xu, W., Z.H. Luo, S. Guo and K.L. Pang. 2016. Fungal community analysis in the deep-sea sediments of the Pacific Ocean assessed by comparison of ITS, $18 \mathrm{~S}$ and $28 \mathrm{~S}$ ribosomal DNA regions. Deep-Sea Res. I10: 951-960.

Xu, W., S. Guo, K.L. Pang and Z.H. Luo. 2017. Fungi associated with chimney and sulfide samples from a South Mid-Atlantic Ridge hydrothermal site: distribution, diversity and abundance. Deep-Sea Res. I123: 48-55.

Xu, W., L.F. Gonga, K.L. Pang and Z.H. Luo. 2018. Fungal diversity in deep-sea sediments of a hydrothermal vent system in the Southwest Indian Ridge. Deep-Sea Res. I131: 16-26.
Zhang, Y., C.L. Schoch, J. Fournier, P.W. Crous, J. de Gruyter, J.H.C. Woudenberg, K. Hirayama, K. Tanaka, S.B. Pointing, J.W. Spatafora and K.D. Hyde. 2009. Multi-locus phylogeny of the Pleosporales: a taxonomic, ecological and evolutionary reevaluation. Stud. Mycol. 64: 85-102.

Zhang, Y., P.W. Crous, C.L. Schoch and K.D. Hyde. 2012. Pleosporales. Fungal Divers. 53: 1-221.

Zhang, S.N., K.D. Hyde, E.B.G. Jones, R. Jeewon, R. Cheewangkoon and J.K. Li. 2019. Striatiguttulaceae, a new pleosporalean family to accommodate Longicorpus and Striatiguttula gen. nov. from palms. MycoKeys 49: 99-129.

\section{Bionotes}

\section{Bandarupalli Devadatha}

Fungal Biotechnology Lab, Department of Biotechnology, School of Life Sciences, Pondicherry University, Kalapet, Pondicherry 605014, India. https://orcid.org/0000-0001-6400-5407

B. Devadatha is a Ph.D student studying fungal biodiversity, taxonomy, molecular phylogeny and anti-quorum sensing potential of secondary metabolites from marine fungi under the supervision of Dr. V. Venkateswara Sarma. Currently a post-doctoral researcher at Centre of Excellence in Fungal Research, Mae Fah Luang University, Chiang Rai, Thailand.

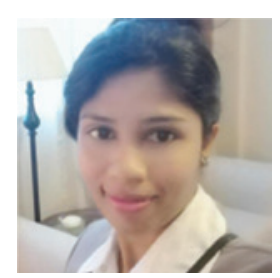

Monika C. Dayarathne

Center of Excellence in Fungal Research, Mae Fah Luang University, Chiang Rai 57100, Thailand; School of Science, Mae Fah Luang University, Chiang Rai 57100, Thailand; World Agro Forestry Centre East and Central Asia Office, 132 Lanhei Road, Kunming 650201, P.R. China; and Key Laboratory for Plant Biodiversity and Biogeography of East Asia (KLPB), Kunming Institute of Botany, Chinese Academy of Science, Kunming 650201, Yunnan, P.R. China

Monika C. Dayarathne is reading her PhD on taxonomy, phylogeny and evolution of marine fungi under the supervision of Prof. Dr. Kevin D. Hyde at Mae Fah Luang University Thailand and the Kunming Institute of Botany, Chinese Academy of Sciences.

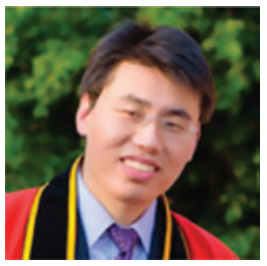

\section{Jian-Kui (Jack) Liu}

School of Life Science and Technology, University of Electronic Science and Technology of China, Chengdu 611731, P.R. China

Jian-Kui (Jack) Liu obtained a PhD degree from Mae Fah Luang University (Thailand) in 2014. He is a researcher in fungal diversity, systemic evolution, plant pathogenic fungi diversity, evolution and speciation at the University of Electronic Science and Technology, the executive editor of the international journal Fungal Diversity, and editor of Phytotaxa. He has published $85 \mathrm{SCl}$ papers and with a H-Index of 27. 


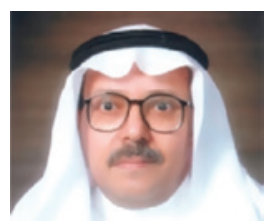

Ali H. Bahkali

Department of Botany and Microbiology,

College of Science, King Saud University, P.O

Box 2455, Riyadh 11451, Kingdom of Saudi

Arabia

Ali H. Bahkali obtained his PhD degree from the University of Wales, UK in 1983. He is working on various topics in mycology, including ecology, physiology and molecular phylogeny.

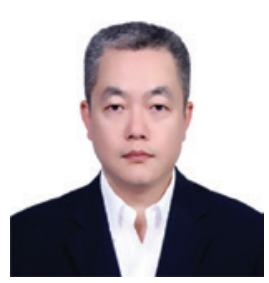

\section{Lei Cai}

State Key Laboratory of Mycology, Institute of Microbiology, Chinese Academy of

Sciences, Beijing 100101, P.R. China

Lei Cai is professor of mycology at the State Key Laboratory of Mycology, Beijing. His research interests are focused on the biodiversity, systematics and evolution of microfungi. Dr. Cai was awarded the prestigious Keisuke Tubaki Medal at the first International Mycological Association Young Mycologist Award for Asia, 2010. He has published circa 170 research articles, with a $\mathrm{H}$-Index of 38. 